\title{
Basement structure of the Paleozoic Platform in Poland
}

\author{
Marek NARKIEWICZ ${ }^{1, *}$ and Zdzisław PETECKI ${ }^{1}$
}

1 Polish Geological Institute - National Research Institute, Rakowiecka 4, 00-975 Warszawa, Poland

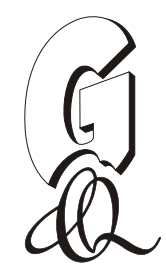

Narkiewicz, M., Petecki, Z., 2017. Basement structure of the Paleozoic Platform in Poland. Geological Quarterly, 61 (2): 502-520, doi: 10.7306/gq.XXXX

The Paleozoic Platform comprises the southwestern half of the Polish territory, separated from the Precambrian East European Platform (EEP) by a NW-SE trending subvertical lithospheric-scale discontinuity - the Teisseyre-Tornquist Zone. In the present study, the Paleozoic Platform basement is subdivided based on geological and geophysical evidence acquired during the last decades, including deep seismic refraction and reflection results, as well as gravity, magnetic and magnetotelluric data. The units adjacent to the EEP, the Mid-Polish Domain (comprising the Łysogóry Block) and the Pomeranian Block, are characterized by a thinned three-layer EEP-type crystalline crust (age 1.7-3.7 Gy). Their oldest platform cover is probably composed of thick Ediacaran syn-rift sedimentary and volcanic rocks. Their western extension in the contiguous German and Baltic area can be traced as far as the East Elbian Massif and Thor Suture based mainly on magnetic anomaly patterns. The Upper Silesian and Małopolska blocks located in SE Poland are characterized by Cadomian (660-600 My) basement overlain by the thick deformed Ediacaran foredeep deposits. Whereas the units with the EEP-type basement are interpreted as proximal terranes displaced along the EEP margin during the late Early Paleozoic, the blocks with a Cadomian basement are conceived as exotic terranes of a possible Gondwanan provenance. All these terranes were accreted ultimately during the final, latest Silurian stages of the Caledonian deformation although the exact scenario of the amalgamation remains hypothetical. The Sudetic Domain in SW Poland is a collage of different crustal units juxtaposed ultimately in the Pennsylvanian (ca. $310 \mathrm{Ma}$ ) during the final episodes of the Variscan Orogeny. Their northern boundary corresponds to the Rheic Suture traceable in magnetic and gravity anomalies pattern along the northern margin of the Wolsztyn-Leszno High, and continuing westwards along the Mid-German Crystalline High. The arcuate trace of the suture in the NE is dextrally displaced along the Odra Fault, and continues southwards where it is mapped as the Moravian-Silesian Suture.

Key words: potential fields, seismics, basement units, Paleozoic Platform, Poland, Caledonides.

\section{INTRODUCTION}

The NW-SE trending tectonic lineament, the TeisseyreTornquist Zone (TTZ) subdivides the territory of Poland into major geological provinces: the East European Platform (EEP) in the NE and the Paleozoic Platform in the SW (Fig. 1). The TTZ corresponds to a major lithospheric boundary separating the cold cratonic, $200 \mathrm{~km}$ thick lithosphere of the EEP from the much thinner (90-120 km) and hotter lithosphere of the Paleozoic Platform (Wilde-Piórko et al., 2010).

The Precambrian crystalline basement of the EEP, although not exposed at the surface, is nevertheless relatively well-studied owing to numerous boreholes and detailed potential-field mapping (Kubicki and Ryka, 1982; Krzemińska et al., in press). In contrast, most of the deep basement south-west of the TTZ, belonging mainly to the extensive Paleozoic Platform of Central and Western Europe (Ziegler, 1990; Guterch et al.,

\footnotetext{
* Corresponding author, e-mail: marek.narkiewicz@pgi.gov.pl
}

Received: November 25, 2016; accepted: February 9, 2017; first published online: XXXX
2010), remains poorly known. The structure and history of this area has been central to a long-lasting controversy on the nature and scenario of the Early Paleozoic and Variscan crustal accretion in Central Europe (Dadlez et al., 1994, 2005; Pharaoh, 1999; Winchester et al., 2002; Pharaoh et al., 2006).

In the last two decades the deep structure of Poland has been studied during successive deep wide-angle reflection/refraction (WARR) seismic projects (summarized by Guterch and Grad, 2006; Guterch et al., 2010; Narkiewicz et al., 2011) and by means of potential field mapping and modeling (Grabowska and Bojdys, 2001; Królikowski, 2006; Petecki, 2008). Of particular importance are the new results of magnetic investigations that contributed to detailed mapping of regional basement units differing in magnitude and pattern of magnetic anomalies (Petecki, 2008). Key new data with far-reaching consequences for the geology of the Paleozoic Platform were recently supplied by the deep reflection seismic profile POLCRUST-01 crossing the TTZ in SE Poland (Malinowski et al., 2013, 2015; Narkiewicz et al., 2015). Recently published results of the regional reflection seismic PolandSPAN Project also provide a new source of data on the deeper structure of the SW margin of the EEP (Mazur et al., 2015, 2016b).

All these results justify a new attempt to review and discuss current knowledge of the deep basement structure of Poland. The present paper is aimed at providing an updated, concise 


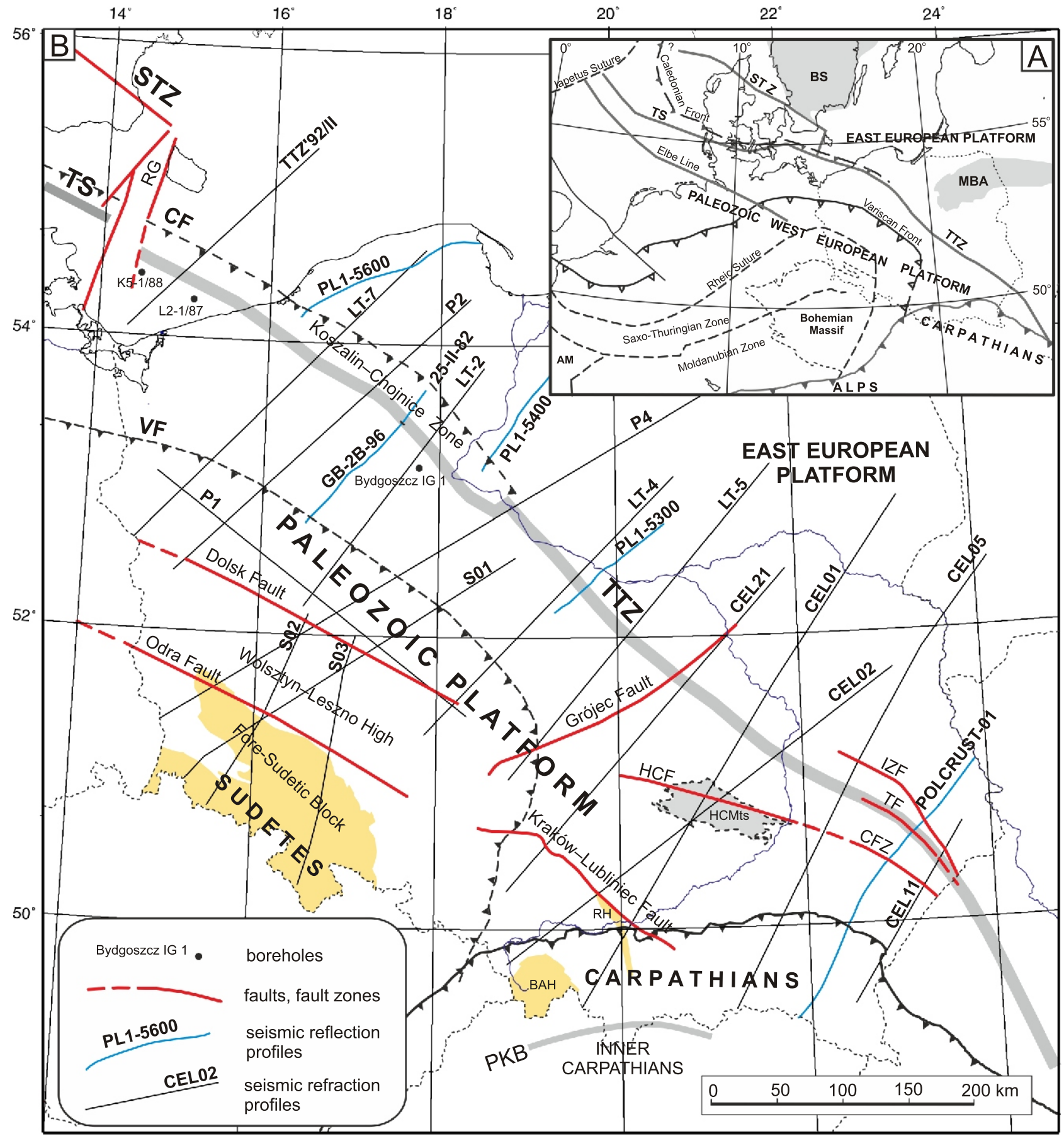

Fig. 1A - tectonic sketch showing location of Poland in a broader Central European context; B - location of deep seismic profiles and selected key boreholes within the tectonic framework of Poland

A - AM - Armorican Massif, BS - Baltic Shield, MBA - Mazury-Belarus Anteclise, STZ - Soregenfrei-Tornquist Zone, TS - Thor Suture, TTZ - Teisseyre-Tornquist Zone; B - in orange - basement occurring at the surface (Sudetes) or in the shallow subsurface (Fore-Sudetic Block, Bielsko-Andrychów High - BAH, Rzeszotary Horst - RH) ; CF - Caledonian Front, CFZ - Cieszanów Fault Zone, HCF - Holy Cross Fault, HCMts - Paleozoic core of the Holy Cross Mountains, IZF - Izbica-Zamość Fault, PKB - Pieniny Klippen Belt, RG - Rønne Graben, TF - Tomaszów Fault, VF - Variscan Front

summary of the subject. The study is focused on defining the main basement units of the Paleozoic Platform and their brief characterization, without going into details of their internal composition and intricacies of their origin. Inevitably, however, some interpretative aspects will be included, and certain broader regional implications are mentioned.

\section{PREVIOUS CONCEPTS}

Detailed historical review of the long-evolving ideas concerning the structure, age and nature of the basement in Poland is beyond the scope of the present paper. The reader is referred to Znosko (1975), Pożaryski et al. (1992) and Dadlez et al. 

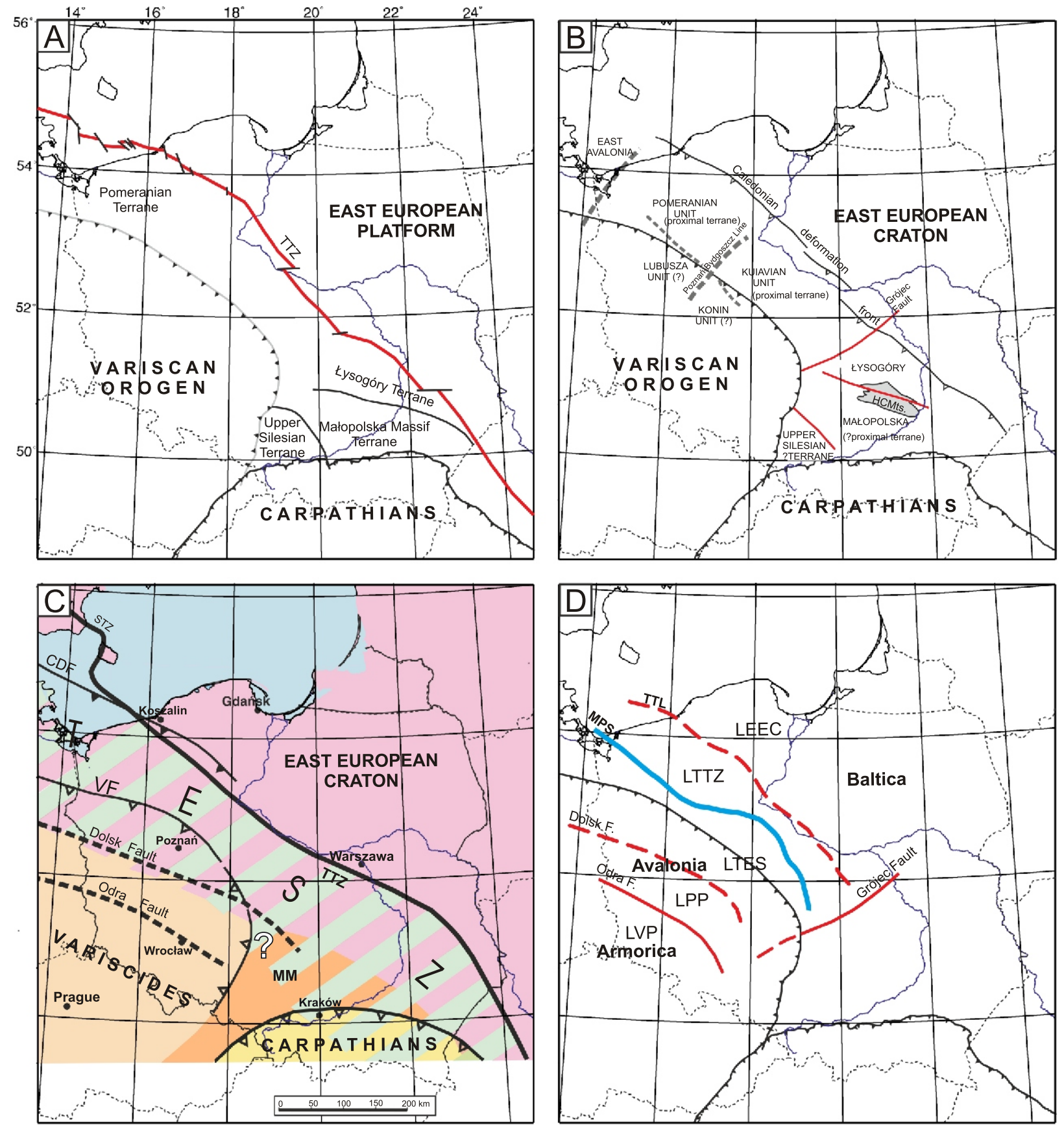

Fig. 2. Previous concepts of the basement structure in Poland according to various authors

A - Pożaryski et al. (1992); B - Dadlez et al. (1994, 2005) and Dadlez (2006); C - Grad et al. (2002) and Guterch and Grad (2006), colour patterns: pink - East European cratonic crust, orange - Variscan crust, green - Avalonia and/or other terranes not affected by Variscan deformation, brown - Małopolska Massif (MM) crust, yellow - Carpathian crust, pink and green strips - high-velocity lower cratonic crust with thick low-velocity cover, CDF - Caledonian Deformation Front; D - Mazur and Jarosiński (2006), abbreviations: LEEC - cratonic lithosphere, LPP - Avalonian crust affected by Variscan deformation, LTES - Avalonian crust unaffected by Variscan deformation, LTTZ - Baltican crust, LVP - Armorican crust, MPS - Mid-Polish Swell boundary (=Avalonia-Baltica boundary), TTL - Teisseyre-Tornquist Line; other explanations as in Figure 1

(1994) for earlier summaries of the subject. This chapter briefly summarizes syntheses of the basement structure of the Paleozoic Platform in Poland published during the last few decades in the context of competing tectonic ideas (Fig. 2).

In the 1990s two opposing concepts prevailed among leading regional geologists in Poland. Pożaryski and his collaborators envisaged the TTZ as a continental-scale sinistral strike-slip fault zone forming the NE boundary of a Caledonian (Early Paleozoic) orogen composed of exotic terranes
(Pożaryski, 1990; Pożaryski et al., 1992; Fig. 2A). The basement was interpreted as weakly metamorphosed Cadomian in the case of the Upper Silesian Terrane, partly anchimetamorphosed early Caledonian-Grampian (560-480 Ma) for the Małopolska Massif Terrane and unspecified "folded complexes of Caledonian Belt terranes" (pre-dating Late Cambrian) for the Łysogóry Terrane. The basement consolidation of the Pomeranian Terrane was dated as Late Ordovician (Taconian), though with no evidence of metamorphism (Pożaryski et al., 1992). 
The other approach, summarized by Dadlez et al. (1994; Fig. 2B), inferred the presence of a Caledonian fold-and-thrust belt overriding the EEP margin. The Łysogóry area was regarded as a part of the EEP and thus characterized by the continuous cratonic basement (Dadlez, 2001). Such basement was implied also in the case of the Małopolska area interpreted as a hypothetical proximal terrane. The Upper Silesian Terrane was tentatively interpreted as an exotic terrane of probable Avalonian (Gondwanan) affinity which would imply Cadomian basement age. In more recent papers, Dadlez et al. (2005) and Dadlez (2006) interpreted the area to the NW of Łysogóry as proximal Kuiavian and Pomeranian terranes. The key argument was the presence of a high P-wave-velocity $(\mathrm{Vp})$ lower crust of EEP type, extending far beyond the TTZ to the SW in the refraction seismic profiles LT-7, POLONAISE P2 and P4 (Dadlez, 1997; Guterch and Grad, 2006). The sutures separating both terranes as well as the tectonic boundary between the Pomeranian Terrane and Avalonia were drawn perpendicularly to the TTZ (Dadlez, 2000; Fig. 2B). The ca. $10 \mathrm{~km}$ thick crustal layer with $V p$ in the range $5.7-5.9 \mathrm{~km} / \mathrm{s}$, underlying supposed Devonian to recent strata, was attributed to highly deformed Lower Paleozoic deposits (Dadlez, 2006).

Grad et al. (2002; see also Guterch and Grad, 2006) envisaged the 100 to $200 \mathrm{~km}$ wide belt along the TTZ to be composed of mixed Avalonian (Gondwanan) and Baltican (EEP-type) crust (Fig. 2C). According to their concept, the former crust is represented by a relatively low-velocity upper layer $(V p<6.0 \mathrm{~km} / \mathrm{s}$ ) extending down to depths of ca. $20 \mathrm{~km}$, and underthrust by an attenuated Baltica margin corresponding to high-velocity lower crust. In SW Poland this type of crust is bounded along the Dolsk Fault by a characteristic "Variscan crust" composed of a lower layer with $V p \sim 6.5-6.6 \mathrm{~km} / \mathrm{s}$ and a much thicker upper layer with $V p \sim 6.2 \mathrm{~km} / \mathrm{s}$. In southeastern Poland, Guterch and Grad (2006: fig. 5) portrayed the "Małopolska Massif crust" (apparently including the Upper Silesian area) and the "crust of the Carpathians", both types displaying a thick Avalonia-type low-velocity upper crust along their NE margins.

Mazur and Jarosiński (2006) presented a modified version of the concept by Grad et al. (2002). According to their interpretation (Fig. 2D) the Baltican (EEP-type) crust labelled as LTTZ extends southwestwards of the TTZ as far as the present SW margin of the Mid-Polish Swell. The latter structure is a broad anticlinorium formed in the latest Cretaceous-earliest Paleogene due to a structural inversion of the NW-SE trending Permian-Mesozoic depocentre (Dadlez et al., 1995). The Avalonian crust extends southwestwards probably as far as the Odra Fault. The northeastern part of Avalonia (LTES; Fig. 2D) was affected by collisional processes during the Early Paleozoic convergence with Baltica whereas its southwestern part (LPP) suffered Variscan deformation during later collision with Armorica. Towards the SE, the LPP, LTES and LTTZ belts terminate approximately against the Grójec Fault - a distinct tectonic discontinuity affecting development of the Permian-Mesozoic structural complex (e.g., Dadlez et al., 1998).

In a recent paper Mazur et al. (2015) returned to the previous idea of the continuous EEP basement extending as far as the Elbe Line in the south-west (Fig. 1A; e.g., Berthelsen, 1998; Bayer et al., 2002). In contrast to the previous concepts, however, the TTZ was interpreted as an old Precambrian suture overlain by a continuous Phanerozoic platform cover. This issue will be more thoroughly discussed below.

\section{TERMINOLOGICAL REMARKS}

In regional geological studies, the term "basement" is usually defined as the lower part of the crust composed of intensely deformed metamorphic or plutonic rocks, mostly unconformably overlain by a sedimentary cover (Allaby and Allaby, 2003; Neuendorf et al., 2005). Dadlez (2006) introduced the notion of consolidated crust/basement, composed of heavily deformed but not necessarily metamorphosed sedimentary and subordinate igneous rocks. Such basement is characteristic of Paleozoic platforms, as opposed to the crystalline crust/basement consisting of metamorphic and igneous rocks typical of Precambrian platforms. More specifically, Dadlez (2006) identified the consolidated crust in the NW and central Poland as a ca. $10-15 \mathrm{~km}$ thick upper crustal layer underlying Devonian-Cenozoic strata and characterized by a P-wave velocity $<6.0 \mathrm{~km} / \mathrm{s}$.

It should be noted that "basement consolidation" appears a rather vague term. It is widely known that young continental crust may be prone to strong deformation, and the degree of tectonism and metamorphism sufficient for the "ultimate consolidation" of the basement can be defined only arbitrarily in such cases. This is, for example, the case of the Variscan (Sudetic) crust, in which the demarcation between the basement and its cover appears rather ambiguous (see below, the section on the Sudetic Domain). The degree of tectonic deformation is a problematic criterion of the basement vs. cover distinction also because of widespread phenomena of thin-skinned folding/thrusting of strata overlying undisputable continental-type basement. For example, the Outer Carpathians are thrust in a series of superimposed nappes above the autochthonous Neogene platform cover in SE Poland (Oszczypko, 2006). Similarly, thin-skinned deformation of Carboniferous flysch overlying Devonian-Carboniferous platform strata are inferred in the Variscan Externides of SW Poland (Grad et al., 2002).

In conclusion, the term "consolidated basement" is here abandoned as ill-defined and arbitrary. Further in the text "basement" will be used in a sense of a crystalline basement, i.e. composed of predominantly igneous and metamorphic rocks of a mesozonal or higher grade. At the same time, the platform cover is here understood in a broad sense, i.e. comprising any strata overlying the crystalline basement. Consequently, the cover, as applied here, may include also weakly metamorphosed (anchimetamorphosed, epizonal) or not metamorphosed strata detached and thrust upon the earlier formed basement and its sedimentary cover.

In the following considerations, the boundaries of particular basement units, corresponding to major crustal discontinuities, are defined using available geological and geophysical data discussed below. The term "block" is applied for the units that appear relatively homogeneous with respect to their internal crustal structure, whereas "domain" denotes regions with a complex, not yet fully recognized deep structure.

In this study the notion of the TTZ is preferred rather than that of the TTL (Teisseyre-Tornquist Line, e.g., Mazur and Jarosiński, 2006; Fig. 2D). It is well-rooted in the literature and, moreover, it seems to better reflect the nature of this ca. $15 \mathrm{~km}$ wide linear tectonic zone. The TTZ defines the NE boundary of the hundreds of kilometres-wide regional unit, the Trans-European Suture Zone (Dadlez et al., 2005; Narkiewicz et al., 2015), stretching along the SW border of the EEP. The TESZ, originally defined by Berthelsen (1993), is commonly conceived as 
the Early Paleozoic accretionary belt between the TTZ and the Variscan Orogen (Pharaoh, 1999; Dadlez et al., 2005). The word "suture" in its name is somewhat misleading as the area in question apparently does not correspond to a single suture. In fact, previous investigations documented its very complex structure comprising subordinate tectonic units with faulted contacts. The latter probably represent (at least in part) accretionary sutures separating basement units defined below. For the above reasons the notion of the TESZ is avoided in further considerations.

\section{MATERIALS AND METHODS}

Direct surface and/or borehole observations of the Paleozoic Platform basement in Poland are possible only in the southern part of the country, in the Sudetes with their immediate foreland (Mazur et al., 2006) and in the sub-Carpathian Bielsko-Andrychów High and Rzeszotary Horst (Buła and Żaba, 2005, 2008; Fig. 1B). In the remaining area, the basement top lies much deeper than $5 \mathrm{~km}$, and consequently it can be investigated only using geophysical techniques and/or extrapolations from the well-studied areas. In this regard, the principal approach applied in many previous studies and followed by the present authors relies on interpretation of modern WARR project results: from the LT-7 profile (Guterch et al., 1994), POLONAISE'97 (Guterch et al., 1999; Janik et al., 2002) to CELEBRATION 2000 (Guterch et al., 2003; Janik et al., 2009; Narkiewicz et al., 2011) and SUDETES (Majdański et al., 2006, 2007; Grad et al., 2008). Moreover the results of the earlier LT experiments have been partly reprocessed and reinterpreted (Grad et al., 2005). The key profiles discussed below are located in Figure 1B.

Part of the WARR profiles was interpreted by Puziewicz (2006) by ascribing certain lithological categories to the layers characterized by their $\mathrm{P}$-wave velocities. In particular, the upper crustal layer with $V p=5.6-5.9 \mathrm{~km} / \mathrm{s}$ was interpreted as sedimentary and volcanic rocks partly metamorphosed to greenschist facies. Consequently, in this study $V p=6 \mathrm{~km} / \mathrm{s}$ is assumed as the boundary value defining the crystalline basement top. Such assumption is consistent with the earlier regional seismic refraction studies in Poland (see Młynarski, 2002). It should be stressed that such an approach excludes the consolidated crust of Dadlez (2006) from the basement concept. This is in contrast to the attitude taken by Grad and Polkowski (2015) in their synthesis of the "seismic basement" in Poland. Although they did not define this notion in terms of $V p$ constraints, it is apparent from their basement depth and $V p$ distribution maps that the consolidated crust of Dadlez (2006) has been included into the seismic basement.

Reflection seismic data used in this study are mainly derived from the POLCRUST-01 profile (Malinowski et al., 2013, 2015; Narkiewicz et al., 2015). This profile provided the first detailed observations on the basement top and internal structure of the lower crust beyond the EEP in Poland. Recently published results of the PolandSPAN Project served as an additional source of information (Mazur et al., 2015, 2016b; see Fig. 1B for location of the profiles).

Potential field evidence includes gravity and magnetic data (Królikowski and Petecki, 1995; Wonik et al., 2001; Banka et al., 2002; Petecki, 2008). Of particular importance are the magnetic anomaly maps accurately reproducing the structure and composition of the crystalline basement under the sedimentary cover (Clark, 1997). The present study was based both on published magnetic data as well as on partly unpublished materials collected by the late $\mathrm{S}$. Wybraniec for the purposes of the
EUROPROBE Programme (Wybraniec, 1999) and the TESZ Working Group (Banka et al., 2002). The data have been reprocessed in order to better visualise major regional features of the basement structure. Lastly, results of magnetotelluric investigations have been also taken into account (Ernst et al., 2002; Jozwiak, 2012).

\section{BASEMENT UNITS IN SOUTHERN POLAND}

The platform cover of southern Poland is thin or absent in many places (Fig. 1B). Consequently, the basement is partly accessible at the surface or in boreholes, and its structure can be traced by potential field mapping more accurately than in the northern part of the Paleozoic Platform. Owing to this, major regional basement units have been generally well-defined during previous investigations (Figs. 3 and 4), particularly in the eastern part of the southern Polish area.

\section{SUDETIC DOMAIN}

The Sudetic Domain is here distinguished as the NE part of the Bohemian Massif outcropping in the West and Central Sudetes and subcropping below the Permian-Cenozoic cover in the Fore-Sudetic Block (Mazur et al., 2006). It broadly corresponds to the "Variscides" as depicted by Grad et al. (2002) and Dadlez et al. (2005: fig. 2), or to the yet earlier concept of the Lower Silesian Internides (Pożaryski et al., 1992).

The internal structure of the Sudetic basement is a complex tectonic collage of several amalgamated tectonostratigraphic units generally ascribed to the Gondwana-derived Armorican Terrane Assemblage (Franke, 2000). They incorporate heavily tectonized and variably metamorphosed fragments of the Neoproterozoic crust, Early-Middle Paleozoic oceanic crust and accretionary prisms, and syn- to post-orogenic Late Devonian to Early Permian piggy-back and intramontane basins and granitoid plutons. The accretion was a multi-stage process spanning the Late Devonian to Late Carboniferous when the present crustal configuration was generally achieved (Mazur et al., 2006). The latest Carboniferous-Early Permian wrench tectonics (Ziegler, 1990) modified the pattern by imposing right-lateral strike-slip displacements mainly along NW-SE trending faults (Aleksandrowski, 1995).

The precise age of the final basement amalgamation is difficult to determine unambigously as strong compressional deformation post-dating the main orogenic events continued into the latest Carboniferous and earliest Permian. It may be assumed that the basement accretion was accomplished in the late Moscovian (ca. $310 \mathrm{Ma}$ ).

The eastern boundary of the Sudetic Domain corresponds to the suture zone between the Central Sudetic terranes and the Brunovistulian basement of the Upper Silesian Block (see below). This Moravian-Silesian Suture is a complex, few kilometres-wide tectonic zone inclined to the WNW, corresponding to the Staré Město Belt and its northern continuation in the Fore-Sudetic Block (Mazur et al., 2006; Kroner et al., 2008; Jastrzębski, 2012). The potential field data analysed do not confirm the northward extension of the suture as far as the TTZ, labelled the "Moravian Line" (Winchester et al., 2002) or "Moravian Suture" (Pharaoh et al., 2006; see also the discussion by Dadlez et al., 2005).

The NE boundary of the domain has been rather poorly constrained by previous studies. It has been considered to correspond to the Odra Fault (e.g., Mazur et al., 2006; Kroner et al., 2008) or to the Dolsk Fault (Grad et al., 2002). The latter fault 


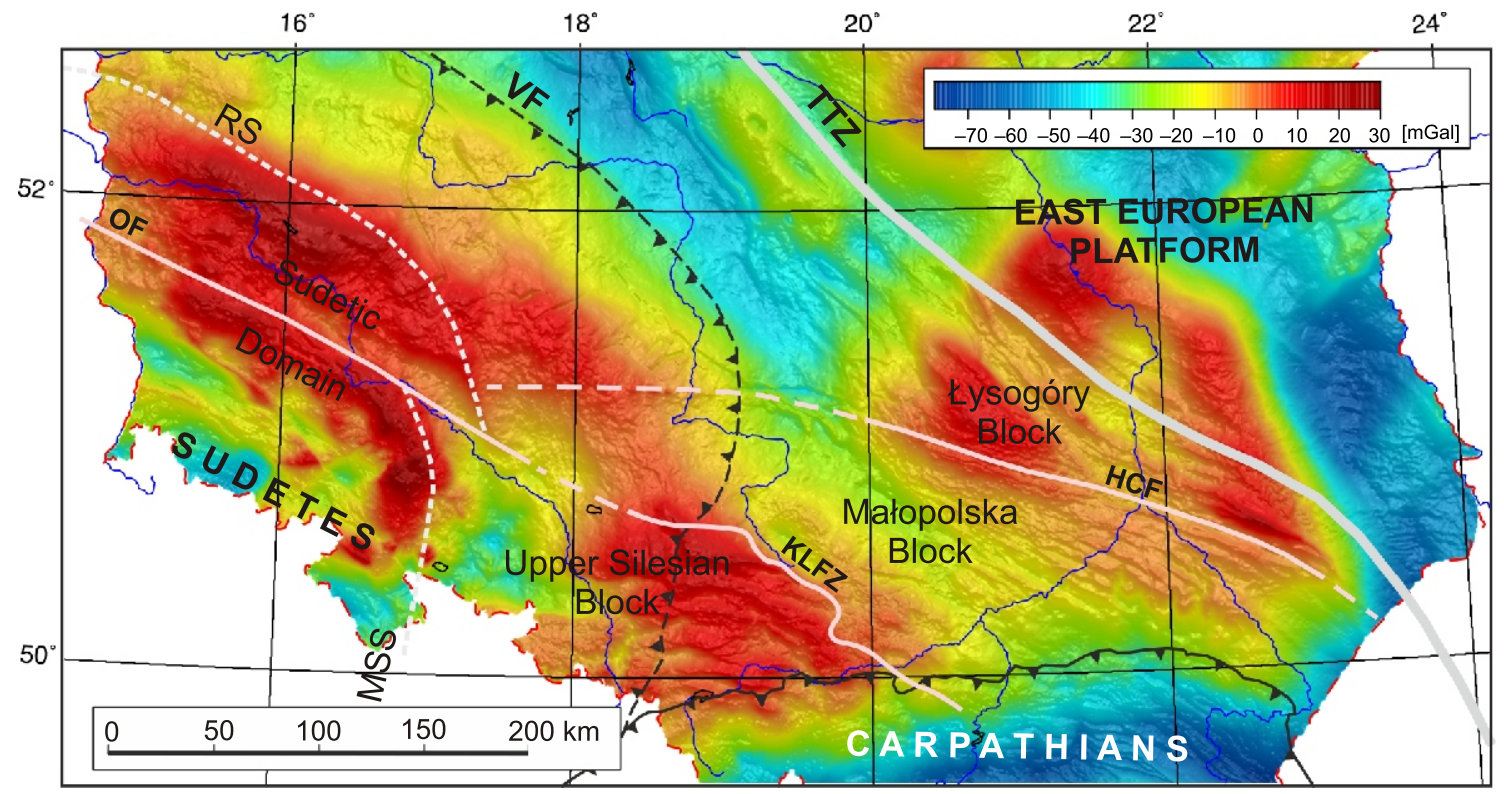

Fig. 3. Bouguer gravity anomaly map of southern Poland (after Królikowski and Petecki, 1995) with location of basement units and main tectonic lines

HCF - Holy Cross Fault, KLFZ - Kraków-Lubliniec Fault Zone, MSS - Moravian-Silesian Suture, OF - Odra Fault, RS - Rheic Suture, TTZ - Teisseyre-Tornquist Zone, VF - Variscan Front

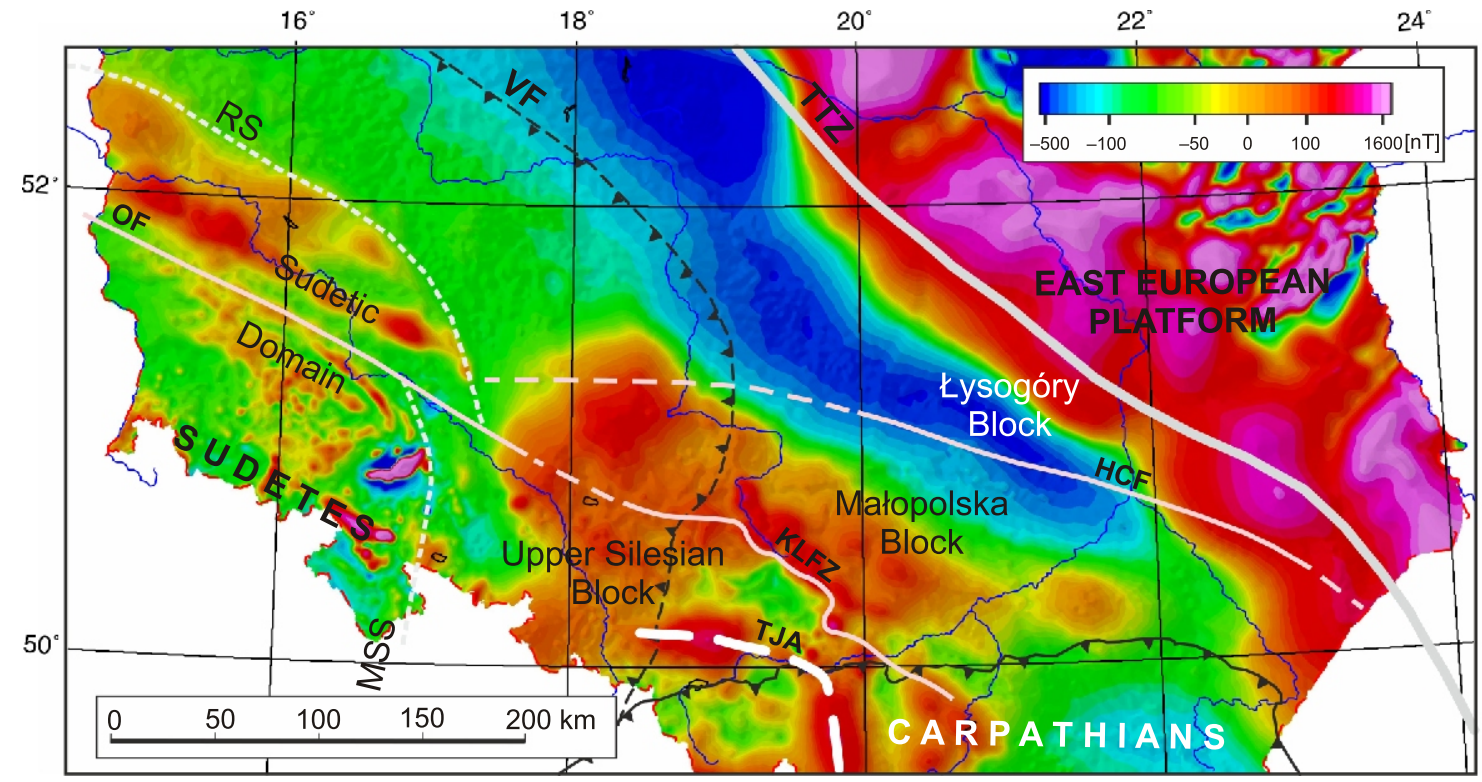

Fig. 4. Reduced to the pole magnetic anomaly map of southern Poland with location of basement units and main tectonic lines

TJA - axis of the Tychy-Jordanów Anomaly; other explanations as in Figure 3

limits from the NE the Wolsztyn-Leszno High forming the sub-Permian elevation of a strongly tectonized and partly metamorphosed Variscan complex (Grocholski, 1975; Mazur et al., 2010). Earlier, the sub-Permian trace of the fault was drawn by Wierzchowska-Kicułowa (1987) ca. $50 \mathrm{~km}$ to the NE of the elevation, based on borehole and shallow refraction seismic data. Afterwards, its location was based on the results of the WARR experiments, in particular the LT-7 and P4 lines (Dadlez, 2006). These profiles revealed a marked subvertical crustal boundary separating the three-layer "TESZ (Mid-Polish) crust" from the two-layer "Sudetian crust" in the SE (Dadlez et al., 2005; Guterch and Grad, 2006).

It should be stressed, however, that the P-wave velocity structure of the Sudetic crust appears very complex, in most cases deviating from the simple two-layer model (Majdański et al., 2007). In particular it includes a high-velocity lower crust $(V p \geq 6.8 \mathrm{~km} / \mathrm{s}$ ) extending to the SW of the Dolsk Fault, reaching as far as the Sudetic Boundary Fault in the SUDETES S03 pro- 


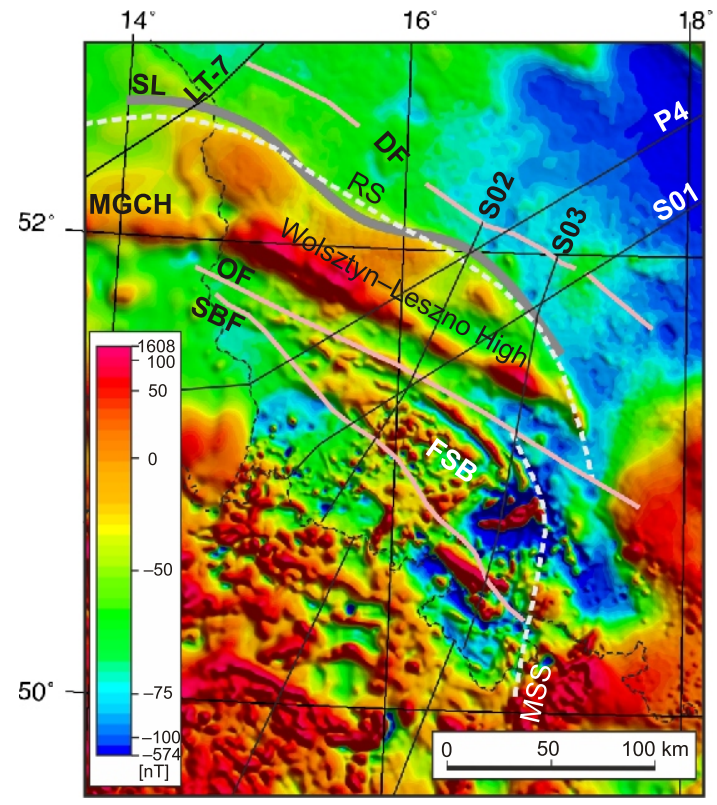

Fig. 5. Reduced to the pole magnetic anomaly map of SW Poland and neighbouring German and Czech areas

Indicated are locations of discussed seismic refraction profiles (black lines), and the main tectonic discontinuities; DF - Dolsk Fault (after Wierzchowska-Kicułowa, 1987), FSB - Fore-Sudetic Block, MGCH Mid-German Crystalline High, MSS - Moravian-Silesian Suture, SBF - Sudetic Boundary Fault, SL - Słubice-Leszno magnetic lineament (after Petecki, 2008); other explanations as in Figure 3

file and even below the entire Polish Sudetes area in the S01 and S02 profiles (Fig. 5; Majdański et al., 2006; Grad et al., 2008). It seems probable that this Vp pattern reflects the complex crustal structure of the Variscan collisional zone and its later history. The orogen was affected by late- to post-orogenic thermal-magmatic events recognized as the Late Paleozoic plutonic and volcanic activity in the area (reviewed by Timmerman, 2008). For example, post-Variscan magmatic underplating and remelting of the lower crust were evoked by Majdański et al. (2007) to explain the high P-wave velocities in the lower crust of the northern Bohemian Massif.

Given insufficient geological constraints and equivocal seismic results, potential field data have been adopted here to trace the NE boundary of the Sudetic Domain. One of the most prominent features is a belt of positive magnetic anomalies trending NW-SE, related to the Wolsztyn-Leszno High. The northern border of this belt corresponds to the gradient zone defined by Petecki (2008) as the Słubice-Leszno magnetic lineament (SL; Fig. 5). The western extension of this zone turns to the SW, passing into the Mid-German Crystalline High (Wonik et al., 2001; Gabriel et al., 2011). The latter structure is interpreted as the NW margin of the Saxothuringian Zone of the Central European Variscides (Franke, 2000; Kroner et al., 2008) corresponding to the Rheic Suture between the Saxothuringian and Rhenohercynian belts.

The positive magnetic anomaly partly overlaps in its westernmost part with the occurrence of the Early Permian volcanic succession that reaches a maximum thickness of $>1 \mathrm{~km}$ just to the east of the Polish-German border (Jackowicz, 1994; Pokorski, 1997). Thus, the Rheic Suture could act here as a zone of pre-existing crustal weakness that controlled post-Variscan magmatism, as did the Kraków-Lubliniec Fault described below (cf. Słaby et al., 2010). Nevertheless, the Permian volcanic rocks have a limited distribution in the Sudetic foreland farther to the SE, and the axis of their maximum thickness is oblique to the trend of the magnetic and gravity anomalies (Pokorski, 1997). This points to a complex relationship between the post-Variscan magmatism and the Variscan tectonic framework, and corroborates the conclusion on older, pre-Permian basement controls of the potential field patterns.

The positive magnetic anomalies form an arcuate southeastern closure towards the Odra Fault (Fig. 5). The fault is interpreted as one of NW-SE trending regional-scale transcurrent zones that shaped the NE margin of the Variscan Orogen in the Late Devonian to Carboniferous (Aleksandrowski, 1995). It became active as a dextral strike-slip fault during the latest Pennsylvanian to Early Permian, most probably being a part of a continental-scale wrench system (Ziegler, 1990; McCann et al., 2006). The pattern of elongated gravity anomalies suggests that the Odra Fault dextrally displaces the course of the Moravian-Silesian Suture by ca. $40 \mathrm{~km}$ relative to the Rheic Suture in the NE (Fig. 3). The magnetic anomaly pattern is less clear (Fig. 5); nevertheless, it also shows an arcuate outline apparently truncated and displaced by the Odra Fault. The fault activity may have been linked kinetically with the late Variscan dextral strike-slip motion documented by Żaba (1999) for the Kraków-Lubliniec Fault (see below).

\section{UPPER SILESIAN BLOCK}

The Upper Silesian Block (USB) forms a northern part of the triangle-shaped Brunovistulicum Terrane neighbouring the Bohemian Massif from the east (Dudek, 1980; Buła and Żaba, 2005). The basement of the block is known mainly from several deep boreholes in the southern, sub-Carpathian part of the unit, in the areas of the Bielsko-Andrychów High and Rzeszotary Horst (Fig. 1B). It is composed predominantly of Neoproterozoic (660-600 Ma) paragneisses (western part) and Paleoproterozoic $(2.0 \mathrm{Ga})$ amphibolites with an Archean protolith $(2.8-2.6 \mathrm{Ga})$ in the east (Buła and Żaba, 2005, 2008). The basement, formed during the Cadomian Orogeny (Finger et al., 2000), is overlain by weakly metamorphosed Ediacaran flysch deposits which in turn are onlapped by various relatively undeformed Paleozoic strata (Moczydłowska, 1997; Buła and Żaba, 2005; Buła et al., 2015). These deposits are known only in the eastern part of the USB, east of the Variscan Front, where the total thickness of the Ediacaran to Cenozoic cover attains up to $8 \mathrm{~km}$ in the central and northern part, decreasing to $2-3 \mathrm{~km}$ in the south and $1 \mathrm{~km}$ in the east. In the western part, the USB basement and its Lower Paleozoic cover is largely inaccessible below the thick, strongly deformed Devonian-Carboniferous strata of the Moravian-Silesian Fold-and-Thrust Belt.

The Moho depth interpreted in the CEL01 and 02 profiles is in the range $33-36 \mathrm{~km}$, while the P-wave velocity structure strongly differs between both profiles (Malinowski et al., 2005; Środa et al., 2006). The difference probably reflects the complex structure of the USB including the Late Proterozoic orogen in the SW and Archean-Paleoproterozoic crystalline rocks in the NE. Both subunits are separated by an arcuate zone of the magnetic Tychy-Jordanów Anomaly representing a hypothetical ophiolite suture (Fig. 4; Buła and Żaba, 2008).

The southern boundary of the USB is hidden below the Carpathians and cannot be directly traced at the basement level. It can be assumed, however, that it conforms with the Peri-Pieniny Fault Zone (Buła and Żaba, 2008) separating the Outer and Inner Carpathians. The NE boundary with the Małopolska Block corresponds to the Kraków-Lubliniec Fault (Buła et al., 1997). The fault is interpreted as a pre-Devonian accretionary suture reactivated during a Variscan 
transtension-transpression, with associated bimodal late- and post-orogenic magmatism (Moczydłowska, 1997; Żaba, 1999 Belka et al., 2002; Słaby et al., 2010). In the CEL01 and CEL02 profiles the fault trace is located approximately in the middle of the $20 \mathrm{~km}$-wide transition between the USB crust and the SW flank of the Małopolska Block crust (Narkiewicz et al., 2011). The northwestern extension of the Kraków-Lubliniec Fault is poorly constrained. It may be hypothesized that it connects with the Odra Fault (Buła and Żaba, 2008).

\section{MAŁOPOLSKA BLOCK}

The Małopolska Block, being a regional equivalent of the Małopolska Massif Terrane of Pożaryski (1990) extends between the USB in the south-west, and the Łysogóry Block in the north and north-east (Figs. 3 and 4). Its basement is unknown, whereas the Ediacaran to Cenozoic cover has been extensively described in previous publications (see, e.g., the reviews by Dadlez et al., 1994; Buła et al., 2008; Narkiewicz et al., 2015). The NE boundary - the Holy Cross Suture - is mapped as the Holy Cross Fault in the Holy Cross Mts. while its SE extension the Cieszanów Fault Zone - can be traced using borehole and geophysical data (Buła et al., 2008). Recently its course has been precisely drawn based on the seismic POLCRUST-01 data and on a residual gravity anomaly pattern (Narkiewicz et al., 2015).

The petrological and sedimentological features of the oldest deposits recognized in the Małopolska Block resemble those of the Ediacaran flysch from the USB (Buła et al., 2008 Żelaźniewicz et al., 2009). Consequently they may be interpreted as representing fragments of the same Neoproterozoic foreland basin. However, the Małopolska Block crust differs from that of the USB in a shallower Moho $(30-35 \mathrm{~km}$ vs. $33-36 \mathrm{~km})$. The low-velocity $(V p \leq 6.0 \mathrm{~km} / \mathrm{s})$ layer composed of sedimentary and low-grade metasedimentary rocks (Malinowski et al., 2005), is much thicker than in the USB. Nevertheless, in the CEL01 profile the P-wave velocity structure of the crystalline crust (with $V p \geq 6.0 \mathrm{~km} / \mathrm{s}$ ) is similar to that of the USB apart from being attenuated (Środa et al., 2006; Narkiewicz et al., 2011). This observation, together with a similar oldest sedimentary cover, suggests that the basement of the Małopolska Block represents an analogous Cadomian crust of Neoproterozoic age (660-600 Ma).

The minimum thickness of the platform cover estimated from the WARR data is between 10 and $15 \mathrm{~km}$ (Narkiewicz et al., 2011). In the Carpathian area the magnetotelluric data document the top of a high-resistivity basement corresponding probably to the crystalline basement top at depths of up to 22 km (Stefaniuk and Klityński, 2007).

\section{ŁYSOGÓRY BLOCK}

The Łysogóry Block occupies a triangle-shaped area between the NNE margin of the Małopolska Block and the East European Platform margin in the NE (Figs. 3 and 4). Towards the SE the unit tapers and probably disappears near Lviv in Ukrainian territory (Narkiewicz et al., 2015). Its basement has not yet been accessed either at the surface or in the deepest boreholes. The oldest deposits of the platform cover known so far are the Middle-Upper Cambrian clastic rocks found in the northern Holy Cross Mts. and in a few boreholes in SE Poland (Dadlez et al., 1994; Belka et al., 2002; Modliński and Szymański, 2005). Along the POLCRUST-01 profile the Early Paleozoic strata are deformed by NE-verging low-angle reverse faults and thrusts, most probably of pre-Devonian (late Caledonian) age (Narkiewicz et al., 2015).
The results of the CELEBRATION 2000 WARR experiment demonstrated a similarity of the Łysogóry and EEP crust, particularly regarding the Moho depth and the presence of a high-velocity lower crustal layer (Narkiewicz et al., 2011). The differences include a thinner Łysogóry crystalline crust, mostly lacking the typical middle layer of the EEP (except for the CEL01 profile), and with a thickened uppermost low-velocity layer. The latter, characterized by $V p<6.0 \mathrm{~km} / \mathrm{s}$, is interpreted as comprising platform sedimentary and volcanic rocks with a total thickness up to $15 \mathrm{~km}$. The Łysogóry crust extends north-westwards along the TTZ, at least to the Grójec Fault (Narkiewicz et al., 2011).

Recent data from the POLCRUST-01 line in the SE part of the Łysogóry Block document the presence of an attenuated EEP-type cratonic crust, the reflective top of which is clearly recorded at depths increasing from ca. $8 \mathrm{~km}$ in the NE to $12 \mathrm{~km}$ and possibly even $15 \mathrm{~km}$ near the Holy Cross Fault (Malinowski et al., 2013; Narkiewicz et al., 2015). The lower crust is similar to that of the neighbouring EEP in displaying a comparable thickness and a characteristic laminar reflectivity.

The oldest members of platform cover inferred from the POLCRUST-01 data are Ediacaran synrift sedimentary and volcanic rocks similar to, although much thicker than, those encountered in a marginal part of the EEP (Narkiewicz et al., 2015). The total thickness of the platform Ediacaran to Cenozoic strata ranges up to $15 \mathrm{~km}$ along the SW margin of the block.

\section{BASEMENT UNITS IN NORTHWESTERN AND CENTRAL POLAND}

\section{POMERANIAN BLOCK}

The present concept of the Pomeranian Block as a basement unit alludes to the earlier ideas of the Pomeranian Terrane (Pożaryski, 1990; Franke, 1994) and Pomeranian Unit (Dadlez et al., 2005; Fig. 2). The basement itself is unknown there, the deepest boreholes penetrating Devonian and Carboniferous epicontinental strata below the Permian cover (Matyja, 2006). Only in a few onshore (Bydgoszcz IG 1) and offshore (L2-1/87 and K5-1/88) boreholes were folded Ordovician and Silurian shales and siltstones encountered below the unconformably overlying Devonian strata (Fig. 1; Dadlez, 2000, 2006; Podhalańska and Modliński, 2006). The Lower Paleozoic strata probably form a part of a fold-and-thrust complex the northeasternmost zone of which is thrust upon the EEP margin. There, the narrow belt of deformed Lower Paleozoic strata (Koszalin-Chojnice Zone, Fig. 1) has been studied in several deep borehole sections (Modliński and Podhalańska, 2010).

In the WARR profiles the Pomeranian Block is characterized by a Moho depth of $37-40 \mathrm{~km}$ which is intermediate between the thick EEP crust and a thinner (30-35 km) crust to the south (Fig. 6). The southern boundary is either marked by a distinct step in the Moho or may be more gradual. The lower crustal layer $(V p \sim 7 \mathrm{~km} / \mathrm{s})$ is relatively thick, attaining $10 \mathrm{~km}$. The middle layer $(V p \sim 6.5-6.7 \mathrm{~km} / \mathrm{s})$ is of a variable thickness, between 6 and $12 \mathrm{~km}$, or can be missing as in the P4 profile. The upper crystalline crust $(V p \sim 6.1-6.3 \mathrm{~km} / \mathrm{s})$ is thick in two southern profiles and missing in the north (P2 and LT-7). The low-velocity $(\mathrm{Vp}<6.0 \mathrm{~km} / \mathrm{s})$ layer is up to $20 \mathrm{~km}$ thick and includes $10-15 \mathrm{~km}$ of presumed sedimentary and volcanic rocks that are partly metamorphosed to greenschist facies (Puziewicz, 2006). The uppermost crustal layer is composed of Devonian to Cenozoic epicontinental strata. Moreover, in the P2 profile there is a lensoid "high-velocity pillow" at the base of the crust, interpreted by Puziewicz (2006) as garnet- and pyroxene-rich granulites, possibly with peridotite lenses, indi- 


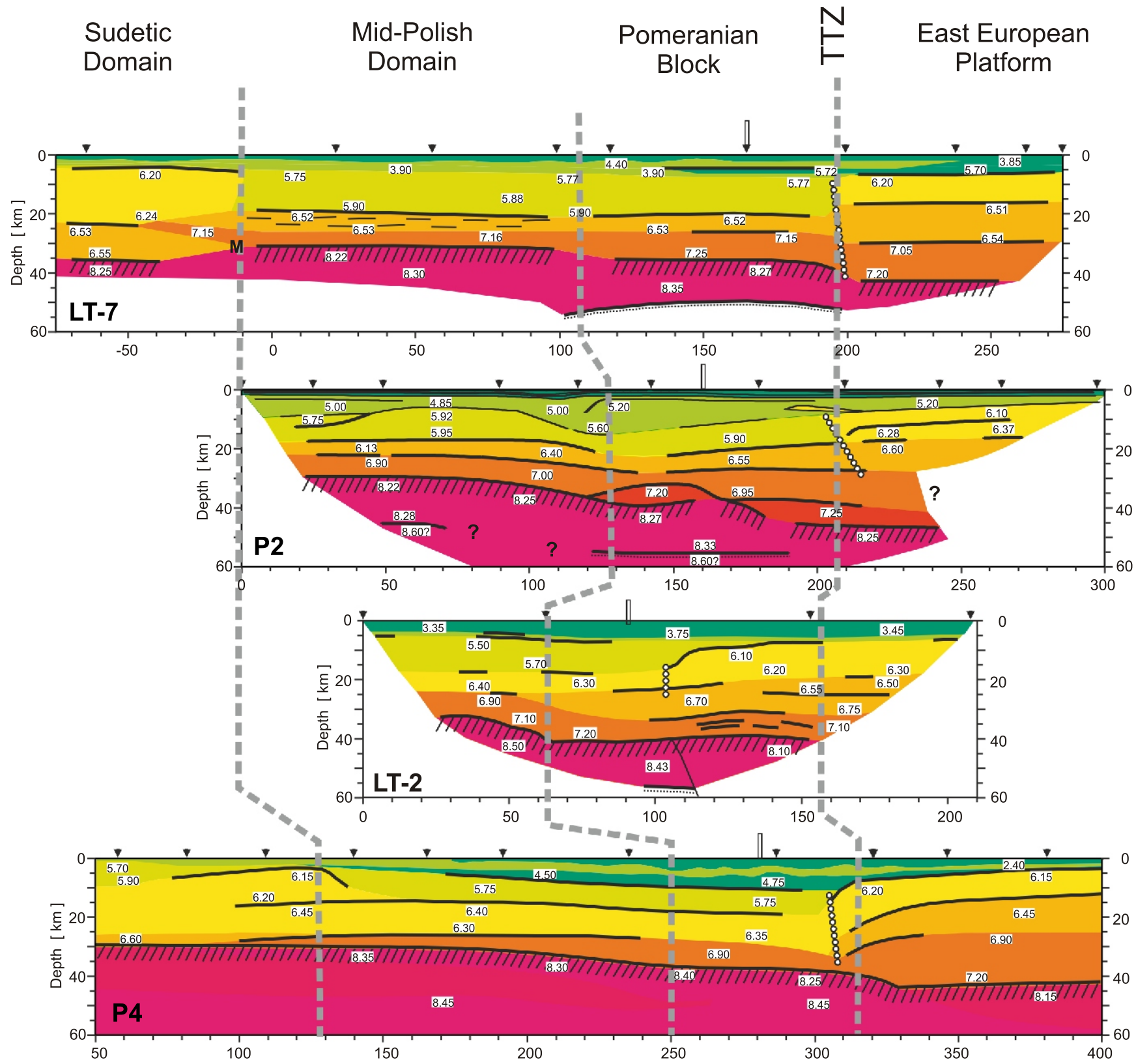

Fig. 6. P-wave velocity structure (after Guterch and Grad, 2006) of the basement units in NW Poland

The Moho is shown by a solid line with oblique hatching below; the seismic lines illustrated are located in Figure 1B

cating magmatic underplating. Other characteristic features found in particular seismic profiles are a high reflectivity of the lower crust (LT-2) and the presence of mantle reflectors at depths of $50-60 \mathrm{~km}$ (Fig. 6).

The extent of the above Pomeranian-type crust, as defined by the $V p$ distribution (Fig. 6), is independently confirmed by potential field data. It corresponds approximately to the area of the deep-seated long-wavelength gravity anomalies visible on the residual map after removal of the gravity effect of the Zechstein-Cenozoic cover from the Bouguer gravity data (Fig. 7; Grobelny and Królikowski, 1988; Królikowski and Petecki, 1997, 2002; Petecki, 2002). The analysis of these sediment-stripped anomalies carried out by the cited authors revealed that the "Pomeranian High" illustrated in Figure 7 has upper mantle and lower crust sources (see also Alasonati Tašárová et al., 2016). Its NE boundary, a distinct horizontal gradient zone striking NW-SE, corresponds to the TTZ, whereas the SW boundary coincides approximately with the Pomeranian crust extent as documented by the WARR data. The superimposed shorter wavelength anomalies can be related to higher-density bodies located at depths of 14-17 km (Petecki, 2008), and thus near the base of the low velocity upper-crustal layer mentioned above. The horizontal gradients associated with the above anomalies strike WNW-ESE and are attributed to high-density mafic plutonic rocks of gabbro or norite composition (Królikowski and Petecki, 1997, 2002; Petecki, 2008). Alternatively, it can be speculated that they reflect the Caledonian thrusts interpreted from boreholes and seismic profiles in the neighbouring German area (Franke, 1994; Hoffman et al., 2008).

The magnetic field is characterized by NW-SE-trending low-amplitude (30-40 nT) anomalies (Fig. 8) the extent of which 


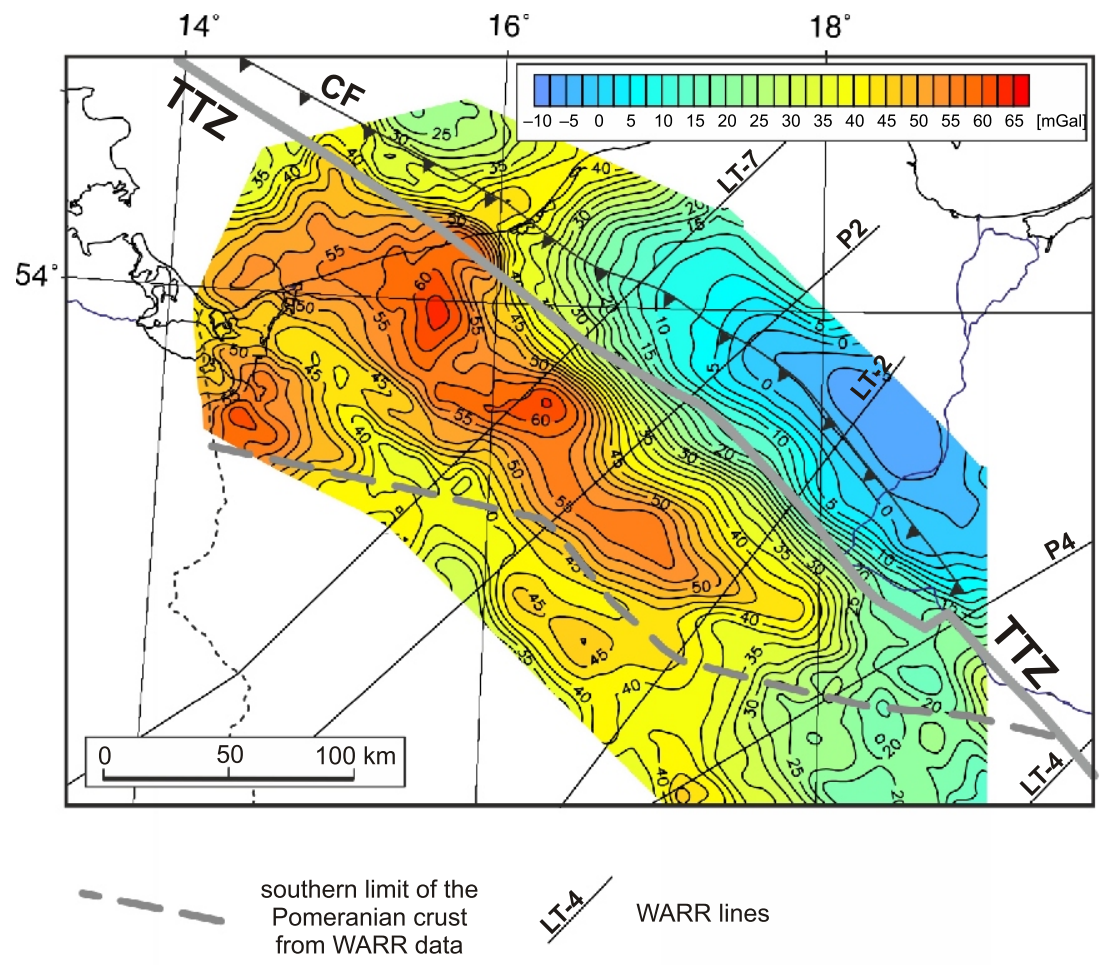

Fig. 7. Stripped gravity map after removal of the gravity effect of the Zechstein-Cenozoic cover from the Bouguer gravity (after Petecki, 2008: fig. 8)

The map reflects the density heterogeneity of the sub-Zechstein rocks in the area of the Pomeranian Block; the extent of the Pomeranian crust is also indicated, based on the WARR data (see the text for further explanations); explanations as in Figure 1B

broadly corresponds to the Pomeranian gravity high. This magnetic province, named the Western Pomerania Anomaly by Królikowski (2006), is bounded to the NE by a steep gradient zone which can be traced almost continuously along the TTZ. The southern boundary of the province corresponds to the well-expressed gradient zone labelled the Szczecin-Stargard-Piła-Inowrocław Magnetic Lineament (SSPI - Petecki, 2008) being here assumed as the southern boundary of the Pomeranian Block. The subdued anomaly pattern characteristic of this unit may suggest a considerable depth to the top of the magnetic basement, covered by a thick layer of non-magnetic rocks. The depth estimates, using the spectral method of Spector and Grant (1970), indicate an average depth to the magnetic basement of ca. $18.5 \mathrm{~km}$ (Petecki, 2001) and thus close to the base of the low-velocity upper crust modelled from the WARR data (Fig. 6). Euler deconvolution applied to two profiles across the SSPI zone indicates that it is best represented as a magnetic contact at depths of 18-23 km, consistent with the depths to the magnetic basement computed using the power spectrum of magnetic data (Petecki, 2008). The cited results of magnetic modelling suggest that the magnetic gradient zone represents an NE-dipping contact in the middle and lower crust.

The western extent of the Pomeranian Block can be tentatively traced based on the magnetic anomaly patterns and using previous geological and geophysical results from NE Germany and the SW Baltic Sea (Fig. 8). In that region the southern margin of the EEP corresponds to the Thor Suture (TS), regarded as the tectonic boundary between Avalonia and Baltica. Some authors assume continuity between the TTZ and TS (e.g., Winchester et al., 2002) but this remains hypothetical (Narkiewicz et al., 2015). The magnetic data suggest a discontinuity coinciding with the southern extension of faults framing the Rønne Graben in the western Baltic Sea area (Fig. 8). The detailed course of the TTZ-TS can be, however, even more complicated due to syn- and post-Variscan transverse faulting (Krauss, 1994).

The SSPI appears to extend westwards for ca. $50 \mathrm{~km}$ across the Polish-German border but its further continuity is uncertain (Fig. 8). It may conform with the course of the Stralsund-Anklam fault system - a deep-seated discontinuity trending WNW-ESE, mapped using deep seismic and magnetotelluric data (Hoffmann and Franke, 1997; Hoffmann et al., 2008). The magnetic anomaly pattern suggests that the Stralsund-Anklam Fault may terminate against the TS in SE Danmark (Fig. 8).

The P-wave velocity structure of the Pomeranian Block is consistent with Baltic (EEP) affinity of the crust (Dadlez, 1997). Consequently, it is here assumed that the basement ages are within a wide range of the Precambrian EEP ages, i.e. 1.7-3.7 Ga (Bogdanova et al., 2008). The platform cover probably includes, in its lower part, autochthonous Neoproterozoic?-lowermost Paleozoic Baltica deposits and superimposed Lower Paleozoic strata of the Caledonian orogenic prism. 


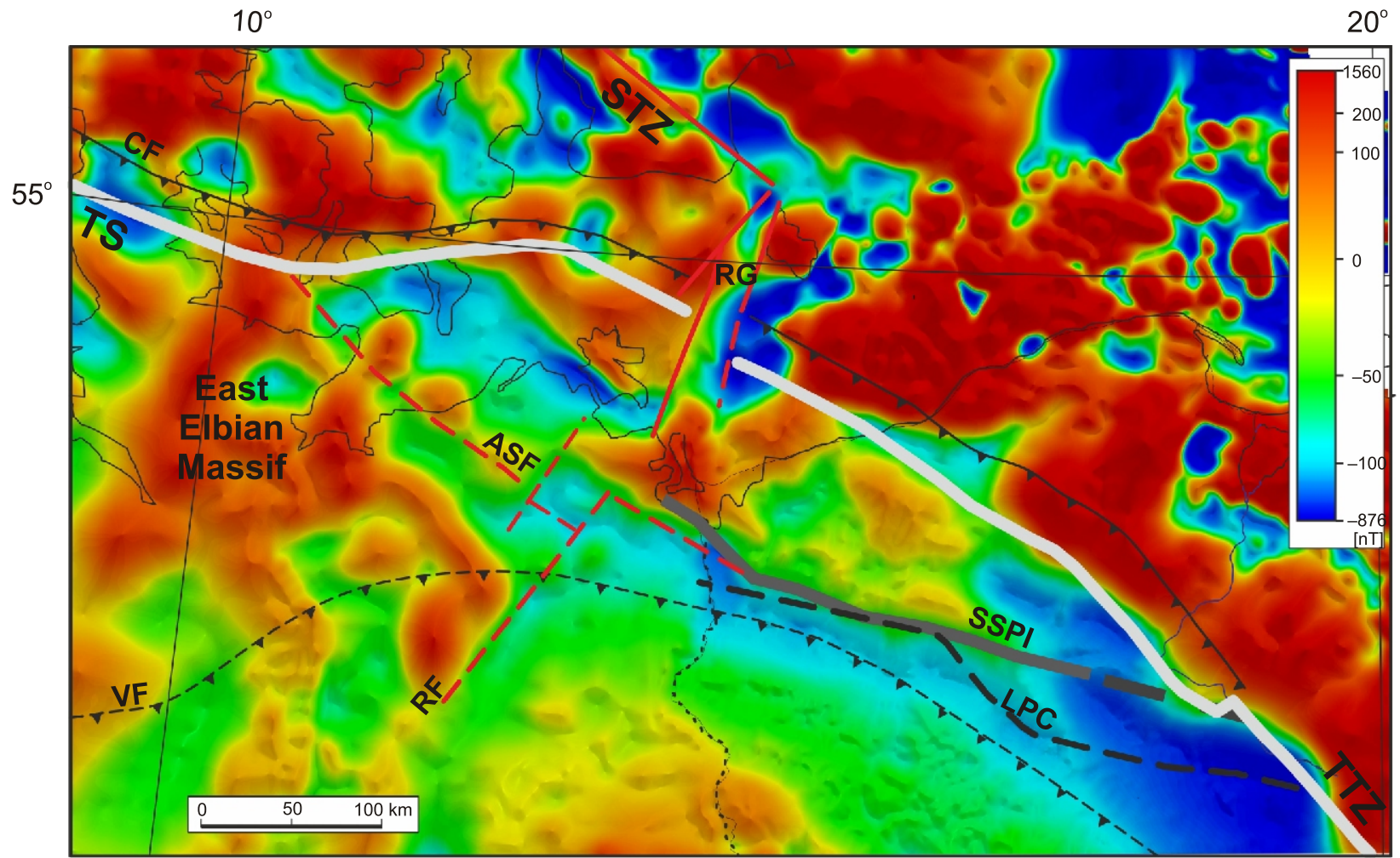

Fig. 8. Reduced to the pole magnetic anomaly map of NW Poland and neighbouring German and Baltic areas showing selected tectonic structures including faults (red lines)

ASF - Anklam-Stralsund Fault, CF - Caledonian Front, LPC - southern limit of the Pomeranian crust after WARR data, RF Rheinberg Fault, RG - Rønne Graben, SSPI - Szczecin-Stargard-Piła-Inowrocław Magnetic Lineament (Petecki, 2008), STZ Sorgenfrei-Tornquist Zone, TS - Thor Suture, TTZ - Teisseyre-Tornquist Zone, VF - Variscan Front

\section{MID-POLISH DOMAIN}

In the area between the Sudetic Domain and Pomeranian Block, not only is the basement unknown but also the pre-Devonian strata have nowhere been found, even in the deepest (>5 km) boreholes.

The series of WARR lines crossing the TTZ and its direct SW neighbourhood document a complex P-wave velocity structure of the area extending from the Łysogóry Block in the SE, beyond the Grójec fault and farther to the NW (Fig. 1; Guterch and Grad, 2006; Narkiewicz et al., 2011). In the SE part, up to the CEL21 line, the Moho depth retains a similar depth as in the neighbouring EEP crust (43-45 km), while from LT-5 northwestwards it nowhere exceeds $40 \mathrm{~km}$, shallowing up to $35-40 \mathrm{~km}$ in the LT-5 to S01 profiles, and to $30-35 \mathrm{~km}$ between the P4 to LT-7 lines. Up to the S01 profile the crust shows a three-layer $V p$ structure, with the lower layer 5-10 km thick and $V p \sim 6.9-7.1 \mathrm{~km} / \mathrm{s}$, the middle layer $5-10 \mathrm{~km}$ thick $(V p=6.4-6.6 \mathrm{~km} / \mathrm{s})$ and the upper one 4-10 km thick $(V p=6.0-6.3 \mathrm{~km} / \mathrm{s})$. The uppermost, low-velocity crust $(V p<6 \mathrm{~km} / \mathrm{s})$ increases in thickness from ca. $10 \mathrm{~km}$ in NE to $20 \mathrm{~km}$ in the SW.

In its central and NW part, the crustal structure of the Mid-Polish Domain is less uniform in terms of the P-wave velocity distribution (Fig. 6). All profiles reveal a high-velocity lower layer $(\mathrm{Vp}=6.9$ to $7.2 \mathrm{~km} / \mathrm{s})$ of variable thickness $(3-10 \mathrm{~km})$. Nevertheless, the typical middle crust $(V p=6.5-6.6 \mathrm{~km} / \mathrm{s})$ is present only in the LT-7 line $(5-7 \mathrm{~km})$, while in the remaining profiles the uppermost low-velocity layer $(V p<6 \mathrm{~km} / \mathrm{s})$ is underlain by a layer with $V p$ values $6.1-6.4 \mathrm{~km} / \mathrm{s}$, intermediate between the middle and upper layers or closer to the latter.
The magnetic anomaly distribution shows a nearly uniform low between the Sudetic Domain in the south-west and the Pomeranian Block in the north (e.g., Królikowski, 2006). The area of the Łysogóry Block and its NW extension towards central and western Poland is consistently characterized by the presence of a high-velocity lower crust and a thick uppermost low-velocity crustal layer. The latter layer, composed of sedimentary rocks and low-grade metasedimentary rocks (Puziewicz, 2006), may be partly responsible for the generally low magnetic anomaly values. Nevertheless, the presence of moderate positive magnetic anomalies in the Pomeranian Block (Fig. 8) indicates that the thick sedimentary cover is not a sufficient condition for suppressing the magnetic effects of the deep basement. Moreover, the results of thermal studies indicate that the Curie isotherm, generally assumed to be the lower limit of magnetized material, is close to a depth of $30 \mathrm{~km}$ in this area (Majorowicz, 2004). Therefore, the lack of magnetic anomalies in the Mid-Polish Domain suggests consistently lower magnetization of the basement rocks in comparison to the neighbouring Sudetic Domain, Małopolska and Łysogóry blocks in the south and the Pomeranian Block in the north. The western extension of the Mid-Polish Domain in eastern Germany is also associated with predominantly negative magnetic anomalies (Gabriel et al., 2011). The magnetic low extends as far as the Rheinberg Fault bounding the East Elbian Massif from the east (Fig. 8; Hoffmann and Franke, 1997).

According to the present interpretation, the Pomeranian Suture between the Pomeranian Block and the Mid-Polish Domain strikes WNW-ESE, that is, approximately parallel to the Holy Cross Suture. Such a trend is indicated by the gravity and magnetic anomaly patterns, particularly by the strike of gradient 
zones (Grobelny and Królikowski, 1988; Królikowski and Petecki, 1997, 2002; Petecki, 2008). Moreover, there is a remarkable similarity between the course of the Pomeranian Suture and the linear deep-seated conductive structure revealed by magnetovariational sounding (Jozwiak, 2012: fig. 3a). The latter structure has been attributed by Jozwiak (2012) to the Variscan Deformation Front. The sub-Zechstein tectonic discontinuities interpreted by Krzywiec (2006) and Krzywiec et al (2006) in NW Poland partly conform with the course of the Pomeranian Suture interpreted in this study. This may indicate that the suture persisted as a zone of a crustal weakness prone to successive Variscan and later deformation.

The available geophysical and geological data do not allow one to place a clear demarcation line between the Łysogóry Block and the remaining part of the Mid-Polish Domain (Figs. 3 and 4). On the other hand, the WARR evidence points to a complex structure of the area between the Variscan Domain and the Pomeranian Block. It may be expected that future work will result in a more detailed subdivision of the Mid-Polish Domain and clarification of its relationship to the Łysogóry Block. In this context, the deep (Caledonian?) controls on the Permian-Mesozoic Grójec Fault development are still to be demonstrated.

\section{DISCUSSION}

The results of the present considerations are summarized in Figure 9 showing the extent of the main basement units of the Paleozoic Platform in Poland, and in Table 1 summarizing their essential characteristics. Generally speaking, these are mostly, with the exception of the Mid-Polish Domain, the entities proposed previously by various authors although considerably redefined here (cf. Fig. 2). In most cases the concept of particular blocks/domains has been changed and their boundaries are modified and more precisely constrained. The following discussion will focus on selected general aspects of the new subdivision as well as on its implications for Paleozoic continental accretion in Poland.

\section{COURSE AND NATURE OF THE TTZ}

Previous ideas on the location and regional significance of the TTZ have been recently summarized by Narkiewicz et al. (2015) and the reader is referred to this publication for an overview. The TTZ course in central and NW Poland (Figs. 7-9) is based mainly on combined magnetic and WARR data (Figs. 6 and 8; see also Dadlez, 2006: fig. 1b). In SE Poland (Figs. 4 and 9) the key evidence was derived from the WARR CELEBRATION 2000 results aided by potential field data (Narkiewicz et al., 2011), subsequently verified and refined using the seismic POLCRUST-01 results and transformed gravity data (Narkiewicz et al., 2015).

Yet, such or similar concepts of the TTZ have not been universally accepted. For example, Berthelsen (1998) argued that the zone is in fact an intraplate pseudosuture of Carboniferous to Early Paleocene age, within a continuous EEP basement ("Baltica crust") extending farther to the SW. In the same vein, Mazur et al. (2015) while maintaining previous ideas of continuous crystalline EEP crust extending far to the west (see the section "Previous concepts"), interpreted the TTZ as an intracratonic suture between two Precambrian blocks of different crustal thickness. Consequently, the continuous Lower Paleozoic cover was interpreted to extend farther south-west beyond the TTZ, above the gradually deepening basement top. The course of the suture was thought to be marked by a gravity low above a Moho step and associated wedge-shaped crustal keel ca. $20 \mathrm{~km}$ wide, protruding ca. $10 \mathrm{~km}$ into the lithospheric mantle. Both crustal features were modelled along the deep seismic reflection profiles PL1-5300 and PL1-5400 (see Fig. 1 for location) mainly based on gravity data. In their reply to the present authors' comment (Narkiewicz and Petecki, 2016) Mazur et al. (2016a) reaffirmed the interpretation of the Precambrian suture. Moreover, in a subsequent study based on the additional profile PL1-5600 (Fig. 1) Mazur et al. (2016b) attributed the TTZ to the Sveconorwegian Orogeny (ca. $1 \mathrm{Ga}$ ).

The present authors, after discussing the concept put forward by Mazur et al. (2015) questioned their idea of the TTZ as an intracratonic Precambrian suture (Narkiewicz and Petecki, 2016). The main objections may be summarized as follows: (1) Mazur et al. (2015) did not document the physical existence of a crustal keel and the presence of an overlying Lower Paleozoic platform cover, (2) the potential field anomaly patterns marking the supposed keel/suture are inconsistent, thus apparently related to different regional subsurface units, (3) no consideration was given to the earlier WARR results and their interpretations (i.a., Guterch and Grad, 2006; Puziewicz, 2006), (4) there was an apparent contradiction between the concept of a gradually deepened basement top across the TTZ and the existence of the first-order horizontal magnetic gradient connected with this structure.

Table 1

Essential characteristics of the Paleozoic Platform basement units in Poland

\begin{tabular}{|l|c|c|c|c|}
\hline \multicolumn{1}{|c|}{ Basement unit } & $\begin{array}{c}\text { Age } \\
{[\mathrm{Ga}]}\end{array}$ & Oldest platform sediments & $\begin{array}{c}\text { Platform cover thickness } \\
{[\mathrm{km}]}\end{array}$ & Tectonic interpretation \\
\hline Sudetic Domain & 0.31 & Late Pennsylvanian & $0-3$ & $\begin{array}{c}\text { amalgamated Armorican terranes } \\
\text { (Variscan Orogen) }\end{array}$ \\
\hline Upper Silesian Block & $0.6-0.66$ & Ediacaran & $1-8$ & Gondwanan terrane \\
\hline Małopolska Block & $0.6-0.66$ & Ediacaran & $10-15\left(22^{*}\right)$ & \multirow{2}{*}{ proximal Baltican terrane (-s) } \\
\hline Mid-Polish Domain & $1.7-3.7$ & Ediacaran? & $8-20$ & proximal Baltican terrane \\
\hline Łysogóry Block & $1.7-3.7$ & Ediacaran? & $8-15$ & up to 20 \\
\hline Pomeranian Block & $1.7-3.7$ & Ediacaran? & &
\end{tabular}

*Based on magnetotelluric data for the Carpathian area (Stefaniuk and Klityński, 2007) 


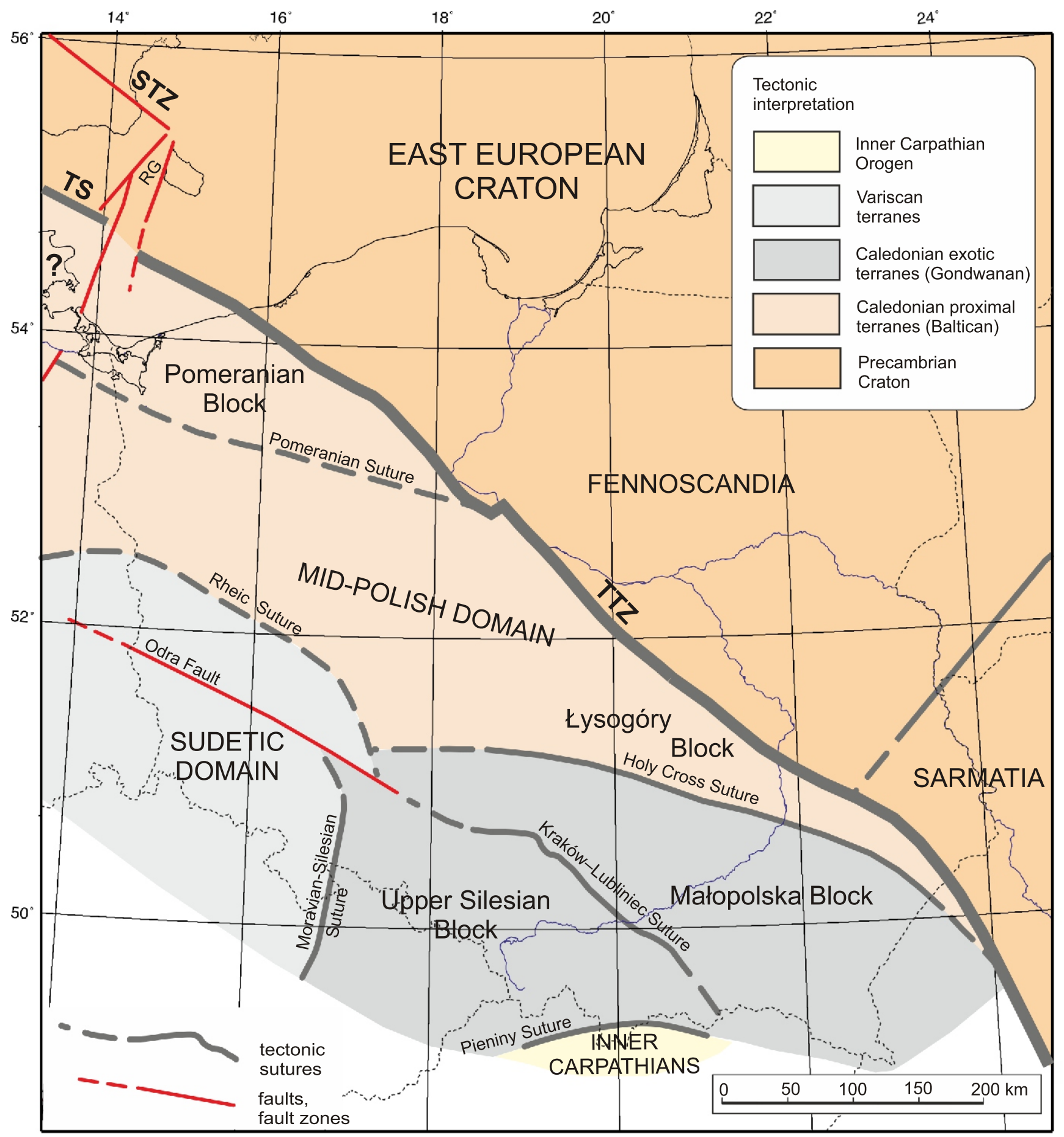

Fig. 9. The main basement units in Poland and their tectonic interpretation,

Fennoscandia-Sarmatia suture after Bogdanova et al. (2015)

Explanations as in Figure 8

In the present authors' opinion, in spite of additional modeling performed by Mazur et al. (2016a), most of the arguments given by Narkiewicz and Petecki (2016) are still valid. In particular the doubts about inadequate evidence of the crustal keel and associated continuous platform cover were not dispelled by Mazur et al. (2016a). The key evidence in this respect ought to have been be provided by the PL1-5300 profile, the only seismic line of those investigated by Mazur et al. (2015, 2016b) which undisputably crosses the TTZ regardless of the interpre- tational variant accepted (cf. Fig. 1). Closer inspection of the seismic interpretation of the line (see fig. 5E in Mazur et al., 2015) reveals that a perfectly smooth, unfaulted basement top as well as the continuous Lower Paleozoic stratigraphic boundaries, particularly in the crucial SW part of the profile, lack support in the seismic record. This conclusion is further corroborated by a comparison of the seismic interpretation of the PL1-5300 profile to those of lines PL1-5400 (Mazur et al., 2015: fig. 6E) and PL1-5600 (Mazur et al., 2016b: fig. 3B). It may be 
seen that both profiles are characterized by much better resolution allowing the cited authors to interpret an uneven crystalline basement top displaced by several faults extending upwards into the Lower Paleozoic cover.

Moreover, the crustal keel marking the alleged Precambrian suture is not evident in Mazur et al. (2015, 2016b) data. The structures quoted by Mazur et al. (2016a) from the WARR profiles P4 (Grad et al., 2003) and TTZ'92/II (Makris and Wang, 1994, see Fig. 1 for a location) are scarcely comparable to the crustal keel interpreted by Mazur et al. (2015, 2016b). They are much wider (100 km vs. $20 \mathrm{~km}$ ) and they display flat or convex top of a lower crust, thus in contrast to the concave geometry shown in the discussed models of Mazur et al. (2015, 2016b).

Obviously, the question of a deep structure of the TTZ is still open to different hypotheses. Future investigations, including high-resolution seismic reflection profiling, are hoped to give more conclusive results in that respect. As for now, however given the above reservations, the concept of the TTZ as a Precambrian intracratonic suture put forward by Mazur et al. (2015) seems to have insufficient support in factual data. Thus, it is not regarded here as a superior alternative to the earlier interpretations by Dadlez et al. (2005), Guterch and Grad (2006), Narkiewicz et al. (2015) and others.

\section{BASEMENT BOUNDARIES: VERTICAL OR INCLINED?}

The geometry of the sutures between the basement units described deserves a separate brief discussion as it is important for their tectonic interpretation, e.g. transcurrent (strike-slip) versus compressional (thrust) regime (Malinowski et al., 2015). Evidently, a thrust geometry characterizes the Moravian-Silesian Suture (e.g., Jastrzębski, 2012). In the case of other sutures depicted in Figure 9, including the TTZ, some interpretations also suggest an inclined or thrust geometry (Królikowski et al., 1996; Dadlez, 2001; Petecki, 2008; Gągała 2015).

The Variscan (late Carboniferous) foreland compression partly overprinted Early Paleozoic structures by generating reverse faults or minor thrusts and horizontal detachments commonly formed due to transpressive reactivation of the pre-existing tectonic discontinuities (Pożaryski et al., 1992; Pożaryski and Tomczyk, 1993; Lamarche et al., 2003; Krzywiec, 2009 Żaba, 1999; summarized by Narkiewicz, 2007). Given such an overprint visible in the Devonian-Carboniferous strata the original pre-Variscan geometry of the basement block boundaries can be interpreted primarily from deep geophysical evidence, including seismic results in particular. In that regard, Narkiewicz et al. (2011) reviewed the WARR data connected with several major tectonic boundaries in SE Poland including the Kraków-Lubliniec Fault, Holy Cross Fault and TTZ. They concluded that, taking into account also published data on different major transcurrent zones worldwide, the analysed $V p$ record can be attributed to relatively narrow $(<20 \mathrm{~km})$ nearly vertical tectonic zones. Similar geometry was earlier interpreted for the Vp patterns connected with the TTZ in north and central Poland (summarized by Guterch and Grad, 2006; Fig. 6).

Recently, the idea of major subvertical boundaries in SE Poland gained strong support from the deep reflection seismic POLCRUST-01 results (Malinowski et al., 2013; Narkiewicz et al., 2015). In particular, the Tomaszów Fault (=TTZ in SE Poland), Izbica-Zamość Fault and Cieszanów Fault Zone (CFZ) are well-documented in the upper sedimentary layer (e.g. Kowalska et al., 2000; Buła et al., 2008; Krzywiec, 2009), and can be traced vertically down to the basement top and to deeper crustal discontinuities discernible in seismic reflectivity patterns (Narkiewicz et al., 2015).

Malinowski et al. (2015) investigated two alternative variants of the Małopolska and Łysogóry blocks boundary assuming either its subvertical orientation (Malinowski et al., 2013; Narkiewicz et al., 2015) or inclination at an angle of ca. $40^{\circ}$ to the SW. The second variant implies continuous EEP-type basement extending below the overthrust Małopolska Block, whereas the Holy Cross Suture forms a crustal-scale, NE-verging thrust terminating as thin-skinned deformation near the base of the Mesozoic cover. However, the gravity-magnetic modeling results appeared inconclusive, supporting both subvertical fault and thrust variants. Malinowski et al. (2015) reviewed available geophysical and geological evidence, and accepted the first variant as the more probable one. The main arguments included: (1) seismic refraction and reflection evidence of a more limited extent of the EEC crust bounded by the vertical trace of the CFZ, (2) a deep vertical conductive zone corresponding to the Holy Cross Suture as constrained by magnetotelluric soundings (Ernst et al., 2002; see also Semenov et al., 1998), (3) a lack of evidence of thrusting in the subsurface Lower Paleozoic strata of the NE Małopolska Block margin, investigated in boreholes and shallow seismic reflection profiles (Kowalska et al., 2000, Maksym et al., 2003; Buła and Habryn, 2011).

Recently, Gagała (2015) discussed a thin-skinned variant of the Caledonian Holy Cross Fault development, controlled by a deep-seated "triangle-zone" - a wedge of the Małopolska Block crust protruding northwards into the Łysogóry Block. Gągała (2015) concluded that assumption of the deep-seated nature of the HCF is an unnecessary complication. Such an approach, however, seems to neglect the geophysical evidence for a crustal-scale discontinuity along the HCF (Semenov et al., 1998; Dadlez, 2001; Narkiewicz et al., 2011). Gągała (2015: fig. 1B) illustrated his concept using reinterpreted POLCRUST-01 results of Malinowski et al. (2013). The reinterpretation, assuming a thrust contact between the Małopolska and Łysogóry blocks is, nevertheless, not backed by any arguments and therefore its validity is hard to assess. Hence, according to the present authors, the thin-skinned scenario of the latest Silurian Holy Cross Fault development as proposed by Gągała (2015) does not appear as a viable alternative to the nearly-vertical Caledonian accretionary suture inferred in the present paper.

In contrast to the TTZ and other basement block boundaries discussed above, the Pomeranian Suture may in fact represent an inclined crustal discontinuity. The magnetic modelling results suggest that the SSPI gradient zone represents a NE-dipping boundary in the middle and lower crust (Petecki, 2008). Moreover, reprocessing of the deep seismic reflection results from profiles GB-2B-96 and 25-III-82 (see Fig. 1 for location) revealed lower crustal and sub-Moho (?) reflectors dipping north-eastwards (Petecki, 2003). These results may indicate that the contact between the Mid-Polish Domain and the Pomeranian Block indeed represents a crustal-scale south-vergent thrust. Nevertheless, definitive proof is still to be demonstrated by e.g. higher-resolution deep seismic reflection profiling.

\section{BASEMENT STRUCTURE AND CALEDONIAN ACCRETION}

The basement units distinguished in SE Poland partly correspond to the Caledonian terranes earlier defined by Pożaryski (1990) and Pożaryski et al. (1992), albeit with considerable modifications. Most importantly, the new POLCRUST-01 data on the 
Łysogóry Block allowed Narkiewicz et al. (2015) to interpret this unit as a proximal terrane with a cratonic and not early Caledonian basement. Thus, in contrast to Dadlez et al. (1994) and Dadlez (2001), the Łysogóry Block is not conceived here as the continuous western extension of the EEP basement covered by Caledonian overthrusts.

The basement of the Małopolska Block, regarded as Caledonian-Grampian (pre-Arenigian) by Pożaryski et al. (1992), is here assumed as Cadomian by analogy to the Upper Silesian Block (Brunovistulian) basement, as discussed above. Consequently, both blocks are interpreted as exotic terranes derived most probably from the peri-Gondwanan Cadomian belt (Narkiewicz et al., 2015). The seismic reflectivity pattern of the deeper Małopolska Block crust shows a series of east-verging thrust- and shear-zones (Malinowski et al., 2013; Narkiewicz et al., 2015). The relationship of this pattern to the deformed and anchimetamorphosed Ediacaran flysch is not clear. The latter may represent a proximal part of a foreland basin involved in thick-skinned thrusts of a Cadomian Orogen. The other possibility is that the deep crustal pattern is related to an earlier orogenic event whereas the flysch represents a superimposed latest Proterozoic foreland basin. The second possibility seems more probable as no trace of basement rocks has been found below the Miocene in hundreds of boreholes drilled in the Carpathian Foreland area so far (Buła et al., 2008). Also, the potential field data do not show any pattern that could be associated with possible basement-cored thrusts. Thus, the preferred interpretation is that the Ediacaran clastic rocks are thrust upon the earlier consolidated basement. It seems probable that the general relationship is similar to that in the USB, i.e. the younger Ediacaran flysch is superposed on the Cadomian basement (660-600 Ma). The main difference between both blocks would consist in a larger post-Ediacaran uplift of the USB, leading to a stronger erosion of the Ediacaran flysch cover.

The basement structure in central and NW Poland and in the adjoining German area belongs to the most controversial issues of Central European regional geology (e.g., Krawczyk et al., 2008). The present concept generally complies with the idea of Caledonian proximal terranes, i.e. detached fragments of Baltica crust (Dadlez, 2000; Dadlez et al., 2005). However, in contrast to Dadlez et al. (2005) and Dadlez (2006), it is here assumed that the sutures bounding the proximal terranes in NW Poland are oblique and not perpendicular to the TTZ (cf. Figs. 2B and 9).

Mazur and Jarosiński (2006) tentatively interpreted the Pomeranian segment of their LTTZ unit (Fig. 2D) as a displaced part of the craton involved in the earlier Avalonia-Baltica collision, thus in agreement with the proximal terrane concept of Dadlez (2000). On the other hand, the idea of the Pomeranian Caledonides by Mazur et al. (2016b) envisages a thin-skinned orogenic belt superimposed on continuous EEP crust with the TTZ acting as a reactivated Precambrian suture limiting the orogenic front from NE. While the thin-skinned character of the outer Caledonide belt is acceptable, the interpretation of the TTZ as a Precambrian suture and, consequently, its reactivation during the Caledonian deformation seem insufficiently founded (cf. the discussion above on the TTZ).

The pattern of basement units of the Paleozoic Platform in Poland reflects two major stages of a continental accretion (Fig. 9). The earlier one took place during the Early Paleozoic and led to a juxtaposition of at least four units separated by WNW-ESE to NW-SE trending sutures (from S to N): the Upper Silesian Block, Małopolska Block, Mid-Polish Domain and Pomeranian Block. The first two are exotic terranes of Gondwanan provenance, while the remaining ones are proxi- mal Baltican terranes, or groups of terranes, the latter being likely in the case of the Mid-Polish Domain. The Sudetic Domain, formed due to the Variscan accretion, is a complex array of crustal units juxtaposed along arcuate Rheic and Moravian-Silesian sutures truncating the earlier Caledonian pattern. Obviously, the domain is a generalized entity that can be further subdivided taking into account previous and, possibly, future investigations.

Assuming dextral strike-slip or oblique Early Paleozoic accretion (Dadlez, 2000; Narkiewicz, 2002) the generally WNW-ESE trend of particular basement units suggests successive docking of the Caledonian terranes starting from the proximal Pomeranian Terrane, followed by the proximal Mid-Polish Terrane(s), Gondwanan Małopolska Terrane and finally by the Gondwanan Brunovistulian Terrane. If true, this interpretation would imply the progressively younger age of the sutures southwards (but see an alternative concept by Kozłowski et al., 2014).

\section{CONCLUSIONS AND OUTLOOK}

This critical review of the results of geophysical and geological investigations from the last few decades has allowed the present authors to reconsider the regional pattern of basement units in the Polish part of the Paleozoic Platform adjoining the Precambrian East European Platform from the SW (Fig. 9). The boundary between these first-order lithospheric units, the Teisseyre-Tornquist Zone, is here conceived as subvertical, lithospheric-scale discontinuity that owes its present geometry primarily to late Early Paleozoic accretionary processes.

The present investigations have confirmed that the basement of SE Poland can be subdivided into three units: Upper Silesian, Małopolska and Łysogóry blocks. The basement of the first two units is of a Neoproterozoic (Cadomian) age (660-600 Ma), whereas the Łysogóry Block has attenuated EEP-type crystalline crust (3.7-1.7 Ga). New basement units are described in central and NW Poland: the Pomeranian Block and the Mid-Polish Domain, the latter composed of the Łysogóry Block and its northwestern extension. The newly-described units are characterized by attenuated crystalline EEP-type crust (3.7-1.7 Ga), and contrasting potential field patterns, particularly visible in the magnetic data. The Pomeranian Suture separating both units is traced as a horizontal magnetic gradient zone - SSPI magnetic lineament (Petecki, 2008). It coincides approximately with the southern boundary of the Pomeranian gravity high caused by the sub-Zechstein substrate, and the less distinct crustal boundary documented by the WARR and magnetovariational data.

The Łysogóry, Mid-Polish and Pomeranian units are here interpreted as proximal Baltican terranes while the Upper Silesian and Małopolska blocks are conceived as exotic terranes of Gondwanan provenance. All these units were finally accreted in late Silurian or earliest Devonian times. The Sudetic Domain in the SW corner of the Polish territory is composed of a complex mosaic of smaller terranes accreted during the final Variscan deformation in the Late Pennsylvanian (ca. $310 \mathrm{Ma}$ ). The northern boundary corresponds to the Rheic Suture traceable in the magnetic and gravity anomaly patterns. It is dextrally displaced by ca. $40 \mathrm{~km}$ by the Odra Fault which was an active strike-slip dislocation during post-Variscan wrenching in the latest Pennsylvanian to Early Permian.

The boundaries between the particular basement units are most probably near-vertical sutures representing transcurrent zones, with the exception of the Rheic/Moravian-Silesian Su- 
ture and, probably, the Pomeranian Suture, that comprise inclined (thrust) boundaries.

The most hypothetical unit of those defined in the present paper is the Mid-Polish Domain which may comprise several subordinate blocks of different structure and origins in NW and central Poland. The relationship of these suspect units to the Łysogóry Block is also conjectural at present. To elucidate these questions more geophysical data is needed, preferably from deep high-resolution reflection seismic profiles applying methodology analogous to that of the POLCRUST-01 project (Malinowski et al., 2013). Also, the exact course and geometry of the boundaries between particular blocks are to be resolved by future regional geophysical studies, both seismic and potential field modeling projects. This refers also to the problem of the TTZ and its NW extension that deserve more detailed examination by means of high-quality reflection seismic profiling. Lastly the Sudetic Domain, in particular its subdivision into distinct terranes and their relationship to the main structural belts of the European Variscides, still pose a challenge for future geological and geophysical studies.

Acknowledgements. This study is an outgrowth of the talk presented by the first author during the seminar "Lithosphere Physics/Planetology" (Institute of Geophysics, Warsaw University, October, 23rd, 2015). MN is grateful to M. Grad, the convener of the seminar, for the inspiration to summarize the data on the Polish basement structure. The authors are indebted to the journal reviewers, Z. Alasonati Tašárová, M. Bielik and W. Geissler for their constructive comments. Funding of the present work was provided by the Polish Geological Institute-NRI statutory funds (project no. 62.9701.1401.00.1).

\section{REFERENCES}

Alasonati Tašárová, Z., Fullea, J., Bielik, M., Środa, P., 2016 Lithospheric structure of Central Europe: Puzzle pieces from Pannonian Basin to Trans-European Suture Zone resolved by geophysical-petrological modeling. Tectonics, 35: 722-753.

Aleksandrowski, P., 1995. The significance of major strike-slip displacements in the development of Variscan structure of the Sudetes (SW Poland) (in Polish with English summary). Przegląd Geologiczny, 43: 745-754.

Allaby, A., Allaby, M., 2003. A Dictionary of Earth Sciences. Oxford University Press, New York.

Banka, D., Pharaoh, T.C., Williamson, J.P., TESZ Project Potential Field Core Group, 2002. Potential field imaging of Palaeozoic orogenic structure in northern and central Europe. Tectonophysics, 360: 23-45

Bayer, U., Grad, M., Pharaoh, T.C., Thybo, H., Guterch, A. Banka, D., Lamarche, J., Lassen, A., Lewerenz, B., Scheck, M., Marotta, A.-M., 2002. The southern margin of the East European Craton: new results from seismic sounding and potential fields between the North Sea and Poland. Tectonophysics, $\mathbf{3 6 0}$ 301-314.

Belka, Z., Valverde-Vaquero, P., Dörr, W., Ahrendt, H., Wemmer, K., Franke, W., Schäfer, J., 2002. Accretion of first Gondwana-derived terranes at the margin of Baltica. Geological Society Special Publications, 201: 19-36.

Berthelsen, A., 1993. Where different geological philosophies meet: the Trans-European Suture Zone. Publications of the Institute of Geophysics, A 20: 19-31.

Berthelsen, A., 1998. The Tornquist Zone northwest of the Carpathians: an intraplate pseudosuture. Geologiska Föreningens i Stockholm Förhandlingar, 120: 223-230.

Bogdanova, S., Bingen, B., Gorbatschev, R., Kheraskova, T.N., Kozlov, V.I., Puchkov, V.N., Volozh, Yu.A., 2008. The East European Craton (Baltica) before and during the assembly of Rodinia. Precambrian Research, 160: 23-45.

Bogdanova, S., Gorbatschev, R., Skridlaite, G., Soesoo, A., Taran, L., Kurlovich, D., 2015. Trans-Baltic Palaeoproterozoic correlations towards the reconstruction of supercontinent Columbia/Nuna. Precambrian Research, 259: 5-33.

Buła, Z., Habryn, R., 2011. Precambrian and Palaeozoic basement of the Carpathian Foredeep and the adjacent Outer Carpathians (SE Poland and western Ukraine). Annales Societatis Geologorum Poloniae, 81: 221-239.

Buła, Z., Żaba, J., 2005. Pozycja tektoniczna Górnośląskiego Zagłębia Węglowego na tle prekambryjskiego i dolnopaleozoicznego podłoża (in Polish). Przewodnik 76
Zjazdu Polskiego Towarzystwa Geologicznego Rudy k/Rybnika: 14-42. Państwowy Instytut Geologiczny, Warszawa.

Buła, Z., Żaba, J., 2008. Structure of the Precambrian basement of the eastern part of the Upper Silesian block (Brunovistulicum) (in Polish with English summary). Przegląd Geologiczny, 56: 473-480.

Buła, Z., Jachowicz, M., Żaba, J., 1997. Principal characteristics of the Upper Silesian Block and Małopolska Block border zone (southern Poland). Geological Magazine, 134: 669-677.

Buła, Z., Byś, I., Florek, R., Habryn, R., Jachowicz, M., Kwarciński, J., Laskowicz, R., Liszka, B., Madej, K., Maksym, A., Markowiak, M., Pietrusiak, M., Probulski, J., Ryłko, W., Salwa, S., Sikora, R., Staryszak, G., Tabol-Wójcik, P., Tomaś, A., Zacharski, J., 2008. Geological-Structural Atlas of the Palaeozoic Basement of the Outer Carpathians and Carpathian Foredeep. Ministerstwo Środowidka, Warszawa.

Buła, Z., Habryn, R., Jachowicz-Zdanowska, M., Żaba, J., 2015. The Precambrian and Lower Palaeozoic of the Brunovistulicum (eastern part of the Upper Silesian Block, southern Poland) the state of the art. Geological Quarterly, 59 (1): 123-134.

Clark, D.A., 1997. Magnetic petrophysics and magnetic petrology: aids to geological interpretation of magnetic surveys. AGSO Journal of Australian Geology \& Geophysics, 17: 83-103.

Dadlez, R., 1997. Seismic profile LT-7 (northwest Poland): geological implications. Geological Magazine, 134: 653-659.

Dadlez, R., 2000. Pomeranian Caledonides (NW Poland), fifty years of controversies: a review and a new concept. Geological Quarterly, 44 (3): 221-236.

Dadlez, R., 2001. Holy Cross Mts. area - crustal structure, geophysical data and general geology. Geological Quarterly, 45 (2): 99-106.

Dadlez, R., 2006. The Polish Basin - relationships between the crystalline, consolidated and sedimentary crust. Geological Quarterly, 50 (1): 43-58.

Dadlez, R., Kowalczewski, Z., Znosko, J., 1994. Some key problems of the pre-Permian tectonics of Poland. Geological Quarterly, 38 (2): 169-190.

Dadlez, R., Narkiewicz, M., Stephenson, R.A., Visser, M.T.M., van Wees, J.D., 1995. Tectonic evolution of the Mid-Polish Trough: modelling implications and significance for central European geology. Tectonophysics, 252: 179-195.

Dadlez, R., Marek, S., Pokorski, J., 1998. Paleogeographic Atlas of Epicontinental Permian and Mesozoic in Poland (1:2 500 000). Państwowy Instytut Geologiczny, Warszawa. 
Dadlez, R., Grad, M., Guterch, A., 2005. Crustal structure below the Polish Basin: is it composed of proximal terranes derived from Baltica? Tectonophysics, 411: 111-128.

Dudek, A., 1980. The crystalline basement block of the Outer Carpathians in Moravia: Bruno-Vistulicum. Rozpravy Československé Akademie Věd - Řada Matematických a Prírodních Věd, 90: 1-85.

Ernst, T., Jankowski, J., Jozwiak, W., Lefeld, J., Logvinov, I., 2002. Geoelectrical model along a profile across the Tornquist-Teisseyre zone in southeastern Poland. Acta Geophysica Polonica, 50: 505-515.

Finger, F., Hanzl, P., Pin, C., von Quadt, A., Steyrer, H.P., 2000. The Brunovistulian: Avalonian Precambrian sequence at the eastern end of the Central European Variscides? Geological Society Special Publications, 179: 103-112.

Franke, D., 1994. The deformational history of the Caledonian terranes at Baltica's southwestern margin. Zeitschrift für Geologische Wissenschaften, 22: 67-80.

Franke, W., 2000. The mid-European segment of the Variscides: tectonostratigraphic units, terrane boundaries and plate tectonic evolution. Geological Society Special Publications, 179: $35-61$.

Gabriel, G., Vogel, D., Scheibe, R., Lindner, H., Pucher, R. et al., 2011. Anomalies of the Earth's total magnetic field in Germany the first complete homogenous data set reveals new opportunities for multiscale geoscientific studies. Geophysical Journal International, 184: 1113-1119.

Gągała, L., 2015. Late Silurian deformation in the Łysogóry Region of the Holy Cross Mountains revisited: restoration of a progressive Caledonian unconformity in the Klonów Anticline and its implications for the kinematics of the Holy Cross Fault (central Poland). Geological Quarterly, 59 (3): 441-456.

Grabowska, T., Bojdys, G., 2001. The border of the East-European Craton in south-eastern Poland based on gravity and magnetic data. Terra Nova, 13: 92-98.

Grad, M., Guterch, A., Mazur, S., 2002. Seismic refraction evidence for continental structure in the central part of the Trans-European Suture Zone in Poland. Geological Society Special Publications, 201: 295-309.

Grad, M., Jensen ,S.L., Keller, G.R., Guterch, A., Thybo, H., Janik,T., Tira ,T., Yliniemi, J., Luosto, U., Motuza, G., Nasedkin, V., Czuba, W., Gaczyński, E., Środa, P., Miller, K.C., Wilde-Piórko, M., Komminaho, K., Jacyna, J., Korabliova, L., 2003. Crustal structure of the Trans-European suture zone region along POLONAISE'97 seismic profile P4. Journal of Geophysical Research, 108: B11, ESE 12, 1-24.

Grad, M., Guterch, A., Polkowska-Purys, A., 2005. Crustal structure of the Trans-European Suture Zone in Central Poland - reinterpretation of the LT-2, LT-4 and LT-5 deep seismic sounding profiles. Geological Quarterly, 49 (3): 243-252.

Grad, M., Guterch, A., Mazur, S., Keller, G.R., Špičák, A., Hrubcova, P., Geissler, W.H., 2008. Lithospheric structure of the Bohemian Massif and adjacent Variscan belt in central Europe based on profile S01 from the SUDETES 2003 experiment. Journal of Geophysical Research, 113: B10304, 1-25.

Grad, M., Polkowski, M., 2015. Seismic basement in Poland. International Journal of Earth Sciences, 105: 1199-1214.

Grobelny, A., Królikowski, C., 1988. Gravimetric anomalies caused by sub-Permian sediments in northwestern Poland (in Polish with English summary). Kwartalnik geologiczny, 32 (3/4): 611-634.

Grocholski, W., 1975. Variscides of southern Wielkopolska (in Polish with English summary). Przegląd Geologiczny, 23: 171-174.

Guterch, A., Grad, M., 2006. Lithospheric structure of the TESZ in Poland based on modern seismic experiments. Geological Quarterly, 50 (1): 23-32.

Guterch, A., Grad, M., Janik, T., Materzok, R., Luosto, U., Yliniemi, J., Lück, E., Schulze, A., Förste, K., 1994. Crustal structure of the transition zone between Precambrian and Variscan Europe from new seismic data along LT-7 profile (NW Poland and eastern Germany). Comptes Rendus de l'Académie des Sciences, Series II, Earth and Planetary Science, 319 : 1489-1496.

Guterch, A., Grad, M., Thybo, H., Keller, G.R., POLONAISE Working Group, 1999. POLONAISE'97 - international seismic experiment between Precambrian and Variscan Europe in Poland. Tectonophysics, 314: 101-121.

Guterch, A., Grad, M., Keller, G.R., Posgay, K., Vozar, J., Špičák, A., Brueckl, E., Hajnal, Z., Thybo, H., Selvi, O., CELEBRATION 2000 Experiment Team, 2003. CELEBRATION 2000 seismic experiment. Studia Geophysica et Geodaetica, 47: 659-669.

Guterch, A., Wybraniec, S., Grad, M., Chadwick, R.A., Krawczyk, C.M., Ziegler, P.A., Thybo, H., De Vos, W., 2010. Crustal structure and structural framework. In: Petroleum Geological Atlas of the Southern Permian Basin Area (eds. J.C. Doornenbal and A.G. Stevenson). EAGE Publications b.v. (Houten): 11-23.

Hoffmann, N., Franke, D., 1997. The Avalonia-Baltica suture in NE Germany - new constraints and alternative interpretations. Zeitschrift für Geologische Wissenschaften, 25: 3-14.

Hoffmann, N., Hengesbach, L., Friedrichs, B., Brink, H.-J., 2008 The contribution of magnetotellurics to an improved understanding of the geological evolution of the North German Basin - review and new results. Zeitschrift der Deutschen Gesellschaft für Geowissenschaften, 159: 591-606.

Jackowicz, E., 1994. Permian volcanic rocks from the northern part of the Fore-Sudetic Monocline (in Polish with English summary). Prace Państwowego Instytutu Geologicznego, 145.

Janik, T., Yliniemi, J., Grad, M., Thybo, H., Tiira, T., Polonaise P2 Group, 2002. Crustal structure across the TESZ along POLONAISE'97 profile P2 in NW Poland. Tectonophysics, 360: 129-152.

Janik, T., Grad, M., Guterch, A., and CELEBRATION 2000 WORKING GROUP, 2009. Seismic structure of the lithosphere between the East European Craton and the Carpathians from the net of CELEBRATION 2000 profiles in SE Poland. Geological Quarterly, 53 (1): 141-158.

Jastrzębski, M., 2012. New insights into the polyphase evolution of the Variscan suture zone: evidence from the Staré Město Belt, NE Bohemian Massif. Geological Magazine, 149: 945-963.

Jozwiak, W., 2012. Large-scale crustal conductivity pattern in Central Europe and its correlation to deep tectonic structures. Pure and Applied Geophysics, 169: 1737-1747.

Kowalska, S., Kranc, A., Maksym, A., Śmist, P., 2000. Geology of the north-eastern part of the Carpathian Foredeep basement, the Lubaczów-Biszcza Region (in Polish with English summary). Nafta-Gaz, 54: 158-178.

Kozłowski, W., Domańska-Siuda, J., Nawrocki, J., 2014. Geochemistry and petrology of the Upper Silurian greywackes from the Holy Cross Mountains (central Poland): implications for the Caledonian history of the southern part of the Trans-European Suture Zone (TESZ). Geological Quarterly, 58 (2): 311-336.

Krauss, M., 1994. The tectonic structure below the southern Baltic Sea and its evolution. Zeitschrift für Geologische Wissenschaften, 22: 19-32.

Krawczyk, C.M., McCann, T., Cocks, L.R.M., England, R., McBride, J., Wybraniec, S., 2008. Caledonian tectonics. The Geology of Central Europe, 1: 301-381.

Kroner, U., Mansy, J-L., Mazur, S., Aleksandrowski, P., Hann, H.P., Huckriede, H., Lacquement, F., Lamarche, J., Ledru, P., Pharaoh, T.C., Zedler, H., Zeh, A., Zulauf, G., 2008. Variscan tectonics. The Geology of Central Europe, 1: 559-664.

Królikowski, C., 2006. Crustal-scale complexity of the contact zone between the Palaeozoic Platform and the East-European Craton in the NW Poland. Geological Quarterly, 50 (1): 33-42.

Królikowski, C., Petecki, Z ., 1995. Gravimetric Atlas of Poland. Państwowy Instytut Geologiczny, Warszawa.

Królikowski, C., Petecki, Z., 1997. Crustal structure at the Trans-European Suture Zone in northwest Poland based on gravity data. Geological Magazine, 134: 661-667. 
Królikowski, C., Petecki, Z., 2002. Lithospheric structure across the Trans-European Suture Zone in NW Poland based on gravity data interpretation. Geological Quarterly, 46 (3): 235-245.

Królikowski, C., Petecki, Z., Dadlez, R., 1996. Vertical discontinuities in the Earth's crust of the TESZ in Poland - gravity data. Geological Quarterly, 40 (2): 155-168.

Krzemińska, E., Krzemiński, L., with contributions by Petecki, Z., Wiszniewska, J., Salwa, S., Żaba, J., Gaidzik, K., Williams, I.S., Rosowiecka, O., Taran, L., Johansson, Ĺ. Pécskay, Z., Demaiffe, D., Grabowski, J., Zieliński, G., in press. Geological Map of Crystalline Basement in the Polish Part of the East European Platform 1:1 000 000. Państwowy Instytut Geologiczny, Warszawa.

Krzywiec, P., 2006. Triassic-Jurassic evolution of the Pomeranian segment of the Mid-Polish Trough-basement tectonics and subsidence patterns. Geological Quarterly, 50 (1): 139-150.

Krzywiec, P., 2009. Devonian-Cretaceous repeated subsidence and uplift along the Teisseyre-Tornquist zone in SE Poland - Insight from seismic data interpretation. Tectonophysics, $\mathbf{4 7 5}$ 142-159.

Krzywiec, P., Wybraniec, S., Petecki, Z., 2006. Basement tectonics of the Mid-Polish Trough in central and northern Poland results of analysis of seismic reflection, gravity and magnetic data (in Polish with English summary). Prace Państwowego Instytutu Geologicznego, 188: 107-130.

Kubicki, S., Ryka, W., 1982. Geological Atlas of Crystalline Basement in Polish Part of the East-European Platform. Państwowy Instytut Geologiczny, Warszawa.

Lamarche, J., Lewandowski, M., Mansy, J-L., Szulczewski, M., 2003. Partitioning pre-, syn- and post-Variscan deformation in the Holy Cross Mountains, eastern Variscan foreland. Geological Society Special Publications, 208: 159-184.

Majdański, M., Grad, M., Guterch, A., the SUDETES 2003 Working Group, 2006. 2-D seismic tomographic and ray tracing modelling of the crustal structure across the Sudetes Mountains basing on SUDETES 2003 experiment data. Tectonophysics, $\mathbf{4 1 3}$ 249-269.

Majdański, M., Kozlovskaya, E., Grad, M., SUDETES 2003 Working Group, 2007. 3D structure of the Earth's crust beneath the northern part of the Bohemian Massif. Tectonophysics, 437 17-36.

Majorowicz, J.A., 2004. Thermal lithosphere across the Trans-European Suture Zone in Poland. Geological Quarterly, 48 (1) $1-14$.

Makris, J., Wang, S-R., 1994. Crustal structure at the Tornquist-Teisseyre zone in the Southern Baltic Sea. Zeitschrift für Geologische Wissenschaften, 22: 47-54

Maksym, A., Śmist, P., Pietrusiak, M., Staryszak, G., Liszka, B. 2003. New data on development of the Lower Paleozoic sediments in the Sędziszów Małopolski-Rzeszów region based on Hermanowa-1 borehole (SE Poland) (in Polish with English summary). Przeglad Geologiczny, 51: 412-418.

Malinowski, M., Żelaźniewicz, A., Grad, M., Guterch, A., Janik T., 2005. Seismic and geological structure of the crust in the transition from Baltica to Palaeozoic Europe in SE Poland CELEBRATION 2000 experiment, profile CEL02. Tectonophysics, 401: 55-77.

Malinowski, M., Guterch, A., Narkiewicz, M., Probulski, J. Maksym, A., Majdański, M., Środa, P., Czuba, W., Gaczyński, E., Grad, M., Janik, T., Jankowski, L., Adamczyk, A., 2013 Deep seismic reflection profile in Central Europe reveals complex pattern of Paleozoic and Alpine accretion at the East European Craton margin. Geophysical Research Letters, 40: 3841-3846

Malinowski, M., Guterch, A., Narkiewicz, M., Petecki, Z., Janik T., Środa P., Maksym, A., Probulski, J., Grad, M., Czuba, W. Gaczyński, E., Majdański, M., Jankowski, L., 2015. Geophysical constraints on the crustal structure of the East European Platform margin and its foreland based on the POLCRUST-01 deep reflection seismic profile. Tectonophysics, 653: 109-126.
Matyja, H., 2006. Stratigraphy and facies development of Devonian and Carboniferous deposits in the Pomeranian Basin and in the western part of the Baltic Basin and palaeogeography of the northern TESZ during Late Palaeozoic times (in Polish with English summary). Prace Państwowego Instytutu Geologicznego, 186: 79-122.

Mazur, S., Jarosiński, M., 2006. Deep basement structure of the Palaeozoic Platform in southwestern Poland in the light of POLONAISE'97 seismic experiment (in Polish with English summary). Prace Państwowego Instytutu Geologicznego, 188: 203-222.

Mazur, S., Aleksandrowski, P., Kryza, R., Oberc-Dziedzic, T., 2006. The Variscan Orogen in Poland. Geological Quarterly, 50 (1): 89-118.

Mazur, S., Aleksandrowski, P., Turniak, K., Krzemiński, L., Mastalerz, K., Górecka-Nowak, A., Kurowski, L., Krzywiec, P., Żelaźniewicz, A., Fanning, M.C., 2010. Uplift and late orogenic deformation of the Central European Variscan belt as revealed by sediment provenance and structural record in the Carboniferous foreland basin of western Poland. International Journal of Earth Sciences, 99: 47-64.

Mazur, S., Mikołajczak, M., Krzywiec, P., Malinowski, M. Buffenmyer, V., Lewandowski, M., 2015. Is the Teisseyre-Tornquist Zone an ancient plate boundary of Baltica? Tectonics, 34: 2465-2477.

Mazur, S., Mikołajczak, M., Krzywiec, P., Malinowski, M., Buffenmyer, V., Lewandowski, M., 2016a. Reply to Comment by $M$. Narkiewicz and Z. Petecki on "Is the Teisseyre-Tornquist Zone an ancient plate boundary of Baltica?" Tectonics, 35: 1600-1607.

Mazur, S., Mikołajczak, M., Krzywiec, P., Malinowski, M., Lewandowski, M., Buffenmyer, V., 2016b. Pomeranian Caledonides, NW Poland - A collisional suture or thin-skinned fold-and-thrust belt? Tectonophysics: 692, Part A: 29-43.

McCann, T., Pascal, C., Timmerman, M.J., Krzywiec, P., López-Gómez, J., Wetzel, A., Krawczyk, C.M., Rieke, H., Lamarche, J., 2006. Post-Variscan (end Carboniferous-Early Permian) basin evolution in western and central Europe. Geological Society Memoir, 32: 355-388.

Młynarski, S., 2002. Seismic refraction investigations in Poland (1964-1978) and their use in continuing studies. Geological Quarterly, 46 (3): 247-253.

Moczydłowska, M., 1997. Proterozoic and Cambrian successions in Upper Silesia: an Avalonian terrane in southern Poland. Geological Magazine, 134: 679-689.

Modliński, Z., Podhalańska, T., 2010. Outline of the lithology and depositional features of the lower Paleozoic strata in the Polish part of the Baltic region. Geological Quarterly, 54 (2): 109-121.

Modliński, Z., Szymański, B., 2005. The Ordovician lithostratigraphy of the Biłgoraj-Narol area (southeastern Poland) (in Polish with English summary). Biuletyn Państwowego Instytutu Geologicznego, 416: 45-79.

Narkiewicz, M., 2002. Ordovician through earliest Devonian development of the Holy Cross Mts. (Poland): constraints from subsidence analysis and thermal maturity data. Geological Quarterly, 46 (3): 255-266.

Narkiewicz, M., 2007. Development and inversion of Devonian and Carboniferous basins in the eastern part of the Variscan foreland (Poland). Geological Quarterly, 51 (3): 231-256.

Narkiewicz, M., Petecki, Z., 2016. Comment on "Is the Teisseyre-Tornquist Zone an ancient plate boundary of Baltica?" by Mazur et al. Tectonics, 35: 1595-1599.

Narkiewicz, M., Grad, M., Guterch, A., Janik, T., 2011. Crustal seismic velocity structure of southern Poland: preserved memory of a pre-Devonian terrane accretion at the East European Platform margin. Geological Magazine, 148: 191-210.

Narkiewicz, M., Maksym, A., Malinowski, M., Grad, M., Guterch, A., Petecki, Z., Probulski, J., Janik, T., Majdański, M., Środa, P., Czuba, W., Gaczyński, E., Jankowski, L., 2015. Transcurrent nature of the Teisseyre-Tornquist Zone in Central 
Europe: Results of the POLCRUST-01 deep reflection seismic profile. International Journal of Earth Sciences, 104: 775-796.

Neuendorf, K.K.E., Mehl, Jr., J.P., Jackson, J.A., 2005. Glossary of Geology, 5th Ed. American Gosciences Institute, Alexandria.

Oszczypko, N., 2006. Late Jurassic-Miocene evolution of the Outer Carpathian fold-and-thrust belt and its foredeep basin (Western Carpathians, Poland). Geological Quarterly, 50 (1): 169-194.

Petecki, Z., 2001. Magnetic evidence for deeply buried crystalline basement southwest of the Teisseyre-Tornquist Line in NW Poland. Acta Geophysica Polonica, 49: 509-515.

Petecki, Z., 2002. Gravity and magnetic modeling along LT-7 profile (in Polish with English summary). Przegląd Geologiczny, 50: 630-633.

Petecki, Z., 2003. Lower crustal reflectivity pattern in the Pomeranian segment of the Trans-European Suture Zone: evidence for Caledonian collision zone. Acta Geophysica Polonica, 51: 63-72.

Petecki, Z., 2008. Magnetic basement in the Pomeranian segment of the Trans-European Suture Zone (NW Poland) (in Polish with English summary). Prace Państwowego Instytutu Geologicznego, 191: 5-72.

Pharaoh, T.C., 1999. Palaeozoic terranes and their lithospheric boundaries within the Trans-European Suture Zone (TESZ): a review. Tectonophysics, 314: 17-41.

Pharaoh, T.C., Winchester, J.A., Verniers, J., Lassen, A., Seghedi, A., 2006. The western accretionary margin of the East European Craton: an overview. Geological Society Memoir, 32 291-311.

Podhalańska, T., Modliński, Z., 2006. Stratygrafia i rozwój facjalny osadów ordowiku i syluru strefy Koszalin-Chojnice, podobieństwa i różnice z obszarem południowo-zachodniej krawędzi kratonu wschodnioeuropejskiego i Rugii (in Polish). Prace Państwowego Instytutu Geologicznego, 186: 39-78.

Pokorski, J., 1997. Rock formations, stratigraphy and paleogeography. The Lower Permian (Rotliegend). Sedimentology, paleogeography, paleotectonics (in Polish with English summary). Prace Państwowego Instytutu Geologicznego, 153: 45-62.

Pożaryski, W., 1990. The Middle Europe Caledonides - wrenching orogen composed of terranes (in Polish with English summary). Przegląd Geologiczny, 38: 1-9.

Pożaryski, W., Tomczyk, H., 1993. Geological cross section through SE Poland (in Polish with English summary). Przegląd Geologiczny, 41: 687-695.

Pożaryski, W., Grocholski, A., Tomczyk, H., Karnkowski, P., Moryc, W., 1992. The tectonic map of Poland in the Variscan epoch (in Polish with English summary). Przegląd Geologiczny, 40: 643-651.

Puziewicz, J., 2006. Lower crust and uppermost mantle rocks in the area of POLONAISE'97 seismic experiment - petrologic-seismic models (in Polish with English summary). Prace Państwowego Instytutu Geologicznego, 188: 53-68.
Semenov, V.Yu., Jankowski, J., Ernst, T., Jóźwiak, W., Pawliszyn, J., Lewandowski, M., 1998. Electromagnetic soundings across the Holy Cross Mountains, Poland. Acta Geophysica Polonica, 46: 171-185.

Słaby, E., Breitkreuz, C., Żaba, J., Domańska-Siuda, J., Gaidzik, K., Falenty, K., Falenty, A., 2010. Magma generation in an alternating transtensional-transpressional regime, the Kraków-Lubliniec Fault Zone, Poland. Lithos, 119: 251-268.

Spector, A., Grant, F.S., 1970. Statistical models for interpreting aeromagnetic data. Geophysics, 35: 293-302.

Stefaniuk, M., Klityński, W., 2007. Strop wysokooporowego podłoża prekambryjskiego, Table III.1. In: Atlas geofizyczny Karpat. PIG NAG, Warszawa (Nr inw. 3097/2014).

Środa, P., Czuba, W., Grad, M., Guterch, A., Tokarski, A., Janik, T., Rauch, M., Keller, G.R., Hegedüs, E., Vozár, J., and CELEBRATION 2000 WORKING GROUP, 2006. Crustal and upper mantle structure of the Western Carpathians from CELEBRATION 2000 profiles CEL01 and CEL04: seismic models and geological implications. Geophysical Journal International, 167: 737-760.

Timmerman, M.J., 2008. Palaeozoic magmatism. The Geology of Central Europe, 1: 665-748.

Wilde-Piórko, M., Świeczak, M., Grad, M., Majdański, M., 2010. Integrated seismic model of the crust and upper mantle of the Trans-European Suture zone between the Precambrian craton and Phanerozoic terranes in central Europe. Tectonophysics, 481: $108-115$

Wierzchowska-Kicułowa, K., 1987. Geological features of the Permian basement in the Fore-Sudetic area (in Polish with English summary). Kwartalnik Geologiczny, 31 (4): 557-568.

Winchester, J.A., the PACE TMR Network Team, 2002. Palaeozoic amalgamation of Central Europe: new results from recent geological and geophysical investigations. Tectonophysics, 360: 5-21.

Wonik, T., Trippler, K., Geipel, H., Greinwald, S., Pashkevitch, I., 2001. Magnetic anomaly map for Northern, Western, and Eastern Europe. Terra Nova, 13: 203-213.

Wybraniec, S., 1999. Transformations and visualization of potential field data. Polish Geological Institute Special Papers, 1: 1-88.

Ziegler, P.A., 1990. Geological Atlas of Western and Central Europe, 2nd edn. Shell Internationale Petroleum Maatschappij BV, Den Haag.

Znosko, J., 1975. Tectonic units of Poland against the background of the tectonics of Europe. Biuletyn Instytutu Geologicznego, 252: $61-75$.

Żaba, J., 1999. The structural evolution of Lower Palaeozoic succession in the Upper Silesia Block and Małopolska Block border zone (southern Poland) (in Polish with English summary). Prace Państwowego Instytutu Geologicznego, 166: 1-162.

Żelaźniewicz, A., Buła, Z., Fanning, M., Seghedi, A., Żaba, J., 2009. More evidence on Neoproterozoic terranes in southern Poland and southeastern Romania. Geological Quarterly, 53 (1): 93-124 